\title{
Influences of initial plankton biomass and mixed layer depths on the outcome of iron-fertilization experiments
}

\section{Modeling iron-fertilization experiments \\ M. Fujii and F. Chai}

\section{Fujii ${ }^{1}$ and F. Chai ${ }^{2}$}

${ }^{1}$ Sustainability Governance Project, Creative Research Initiative, Hokkaido University, N9W8, Kita-ku, Sapporo, Hokkaido 060-0809, Japan

${ }^{2}$ School of Marine Sciences, 5706 Aubert Hall, Univ. of Maine, Orono, ME 04469-5706, USA

Received: 9 November 2007 - Accepted: 10 November 2007 - Published: 27 November 2007 Correspondence to: M. Fujii (mfujii@sgp.hokudai.ac.jp)

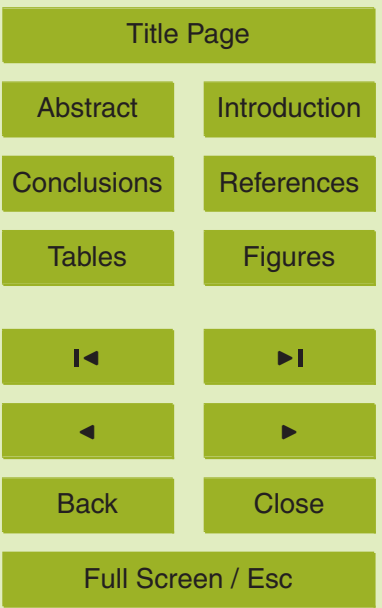

Printer-friendly Version

Interactive Discussion 


\section{Abstract}

Several in situ iron-enrichment experiments have been conducted, where the response of the phytoplankton community differed. We use a marine ecosystem model to investigate the effect of iron on phytoplankton in response to different initial plankton 5 conditions and mixed layer depths. Sensitivity analysis of the model results to the mixed layer depths reveals that the modeled response to the same iron enhancement treatment differed dramatically according to the different mixed layer depth. The magnitude of the iron-induced biogeochemical responses in the surface water, such as maximum chlorophyll, is inversely correlated with the mixed layer depth, as observed.

10 The significant decrease in maximum surface chlorophyll with mixed layer depth results from the difference in diatom concentration in the mixed layer, which is determined by vertical mixing. Sensitivity of the model to initial mesozooplankton (as grazers on diatoms) biomass shows that column-integrated net community production and export production are strongly controlled by the initial mesozooplankton biomass. Higher ini15 tial mesozooplankton biomass yields high grazing pressure on diatoms, which results in less accumulation of diatom biomass. The initial diatom biomass is also important to the outcome of iron enrichment but is not as crucial as the mixed layer depth and the initial mesozooplankton biomass. This modeling study suggests not only mixed layer depth but also the initial biomass of diatoms and its principle grazers are crucial factors in the response of the phytoplankton community to the iron enrichments, and should be considered in designing future iron-enrichment experiments.

\section{Introduction}

In high-nutrient, low-chlorophyll (HNLC) regions, the availability of iron to phytoplankton plays an important role in determining phytoplankton growth (e.g., Martin and Fitzwater, 25 1988; Banse, 1990; Martin, 1990). To confirm this iron-limitation hypothesis, several in situ iron-enrichment experiments have been conducted in the HNLC regions (e.g.,
BGD

4, 4411-4441, 2007

\section{Modeling iron-fertilization experiments}

M. Fujii and F. Chai

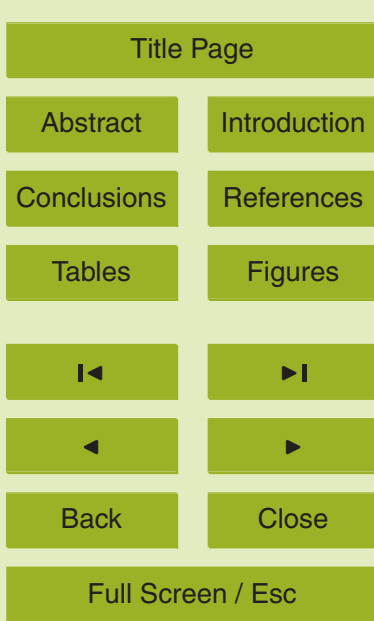

Printer-friendly Version

Interactive Discussion 
Coale et al., 1996, 2004; Boyd et al., 2000, 2004; Gervais et al., 2002; Tsuda et al., 2003). However, the observed responses of the phytoplankton communities are dramatically different among these iron experiments in the HNLC regions (e.g., de Baar et al., 2005; Fujii et al., 2005). For example, the iron-induced maximum surface chloro5 phyll and decrease of $\mathrm{pCO}_{2}$ at the surface $\left(\mathrm{pCO}_{2 \text { sea }}\right)$ were as large as $19\left[\mathrm{mg} \mathrm{m}^{-3}\right]$ and 94 [ $\mu \mathrm{atm}$ ] at SEEDS (the Subarctic Pacific Iron Experiment for Ecosystem Dynamics Study) in the subarctic western North Pacific (Tsuda et al., 2003), but as small as 2 $\left[\mathrm{mg} \mathrm{m}^{-3}\right]$ and 20 through $30[\mu \mathrm{atm}]$ at SOIREE (The first Southern Ocean Iron Release Experiment; Boyd et al., 2000) and EisenEx (The Carbondioxide Uptake South10 ern Ocean (CARUSO)/Eisen(=Iron) Experiment; Gervais et al., 2002) in the Southern Ocean.

Through the comparison of eight iron experiments, de Baar et al. (2005) showed that the iron-induced maximum chlorophyll, the maximum DIC removal, and the overall DIC/Fe efficiency all scale inversely with the mixed layer depth (MLD) defining the 15 light environment, and that lateral patch dilution, sea surface irradiance, temperature, and grazing play additional roles. Applying a marine ecosystem model to SEEDS, Fujii et al. (2005) used sensitivity analysis to show that the water temperature significantly controls both the timing and magnitude of the iron-induced diatom bloom, and that the e-ratio (a ratio of export production to net community production) is inversely correlated with temperature. Their model sensitivity studies on the duration of the iron enrichment also revealed that multiple iron infusions for longer than a week would not be effective at SEEDS because of the stronger silicate limitations during the later phase of the diatom bloom. In other words, the initial dissolved silicate does affect the duration of the bloom, although formal sensitivity analysis of initial dissolved silicate was not conducted. These previous observational and modeling studies suggest that the physical and chemical environmental conditions, other than iron, are also predominant factors in controlling biogeochemical responses to iron enrichments.

On the other hand, recent observational data has shown that the increases in phytoplankton biomass inside the iron patch were dramatically different between SEEDS

BGD

4, 4411-4441, 2007

\section{Modeling iron-fertilization experiments}

M. Fujii and F. Chai

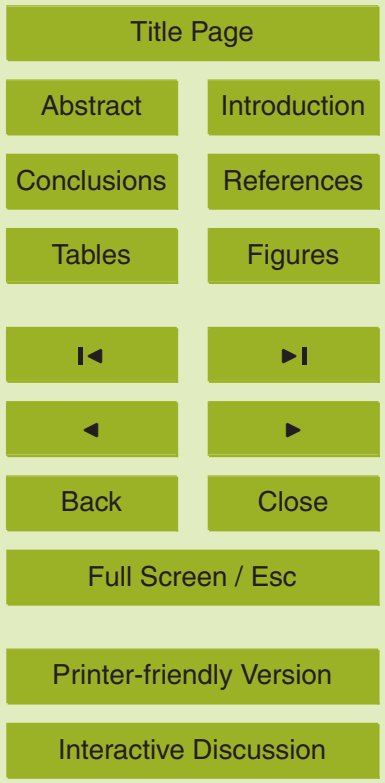

EGU 
and SEEDS II, which were conducted in the same location and the same season of the year (Tsuda et al., 2007) when physical and chemical environmental conditions were very similar. These results imply that factors, other than just physical and chemical environmental conditions, could also significantly determine the response 5 of the phytoplankton community to the iron addition. Landry et al. (2000a, b) and Rollwagen-Bollens and Landry (2000) suggested that grazing processes and/or major nutrient limitations regulate iron-induced phytoplankton biomass accumulation. Grazing pressure is also related to the initial zooplankton biomass when the iron is being introduced to the experimental site. Since the initial physical, chemical, and plankton 10 conditions may vary widely among different iron enrichment experiments, it is difficult to isolate, solely by observation, the key factors that regulate the iron-induced phytoplankton bloom. This necessitates more rigorous verification by application of a generic plankton ecosystem simulation model to the iron experiments (de Baar et al., 2005).

Taking into consideration the suite of environmental variables each of which, more 15 or less, controls the response to in situ iron fertilization, the sensitivity to water temperature and duration of SEEDS have previously been assessed (Fuji et al., 2005), with additional implications for sensitivity to initial dissolved silicate. Sensitivity to variations of incident irradiance on the one hand is so strong that it is deemed low priority for special study. On the other hand lateral patch dilution has been so poorly defined in field 20 observations thus far, that it first requires a sophisticated dilution/mixing description, before sensitivity analysis in a plankton ecosystem simulation model can be feasible.

Here, we use a marine ecosystem model to examine the response of the phytoplankton community to selected different physical environmental conditions and different initial plankton conditions, focusing on the sensitivity of the model results to the MLD and the initial biomass of diatoms and mesozooplankton, the latter being major grazers on diatoms. In the following section we describe the ecosystem model to be used and the experimental design with changes in the MLD and initial plankton biomass. The results based on variations of SEEDS and their implications also for the other fertilization experiments are discussed in Section 3 and a summary is presented in Sect. 4.

\section{BGD}

4, 4411-4441, 2007

\section{Modeling iron-fertilization experiments}

M. Fujii and F. Chai

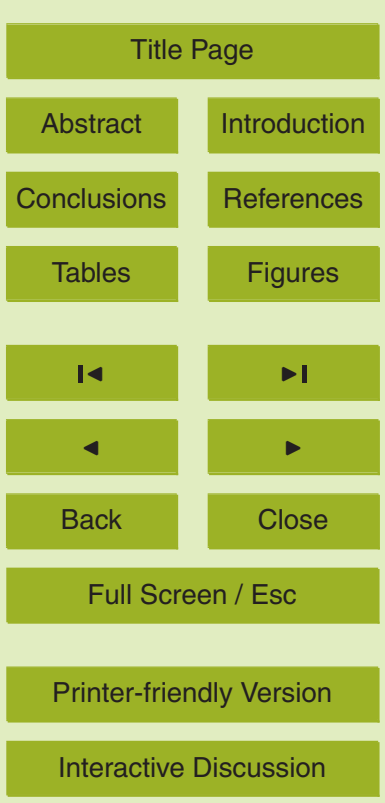

EGU 


\section{Model description and experimental design}

We used a 16-compartment marine ecosystem model (e.g., Fujii et al., 2002, 2005; Yamanaka et al., 2004; Fig. 1). In this model, phytoplankton and zooplankton are categorized by their functional groups in view of the food web (Landry et al., 2000; 5 Rollwagen Bollens and Landry, 2000; Hall and Safi, 2001; Hannon et al., 2001; Saito et al., 2005 and 2006; Suzuki et al., 2005; Takeda and Tsuda, 2005; Tsuda et al., 2003).

Phytoplankton are categorized into two groups: diatoms (PL) including large chainforming centric diatoms Chaetoceros debilis, and smaller phytoplankton (PS) including autotrophic nanoflagellates and coccolithophorids. Phytoplankton components utilize nitrate $\left(\mathrm{NO}_{3}\right)$ and ammonia $\left(\mathrm{NH}_{4}\right)$ in the process of photosynthesis and produce soft tissue in the form of particulate organic nitrogen (PON). Along with photosynthesis, diatoms utilize silicate $\left(\mathrm{Si}(\mathrm{OH})_{4}\right)$ to produce frustules in the form of biogenic silica.

Zooplankton are categorized into three groups: diatom-grazing micro- or mesozoo15 plankton (ZL) including copepoda, ciliates and the heterotrophic dinoflagellate Gyrodinium sp., predatory macrozooplankton (ZP) including carnivorous Chaetogratha, and other non-diatom grazing microzooplankton (ZS) including heterotrophic dinoflagellate Gyrodinium fusiforme s.I. and foraminifera. Coccolithophorids and foraminifera produce hard shells of calcium carbonate $\left(\mathrm{CaCO}_{3}\right)$. Detailed zooplankton dynamics, such as the ontogenetic vertical migration and the reproductive cycle, are not considered in the current modeling study. These processes may not influence model results for a short experimental period ( 60 days or less) and during the summer months in a significant way.

Total alkalinity (TAlk) is calculated by the balances of $\mathrm{CaCO}_{3}, \mathrm{NO}_{3}$ and $\mathrm{NH}_{4}$. The dissolved inorganic carbon (DIC) is calculated by the balances of TAlk, $\mathrm{NO}_{3}$ and $\mathrm{NH}_{4}$ (with a carbon to nitrogen ratio of 6.625; Redfield et al., 1963). Therefore, the partial pressure of $\mathrm{CO}_{2}$ at the sea surface $\left(\left(\mathrm{pCO}_{2}\right)_{\text {sea }}\right)$ is calculated and the air-sea $\mathrm{CO}_{2}$ flux can be estimated by this model.

BGD

4, 4411-4441, 2007

M. Fujii and F. Chai

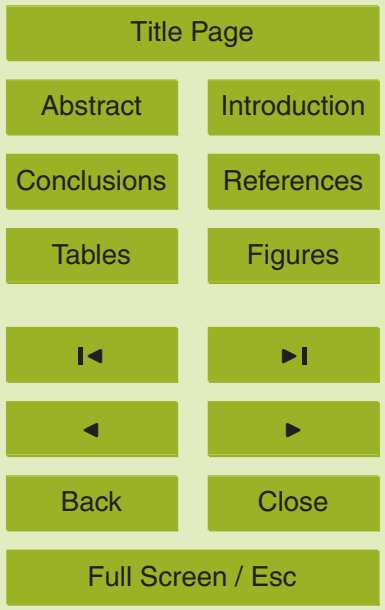

Printer-friendly Version

Interactive Discussion 
The ecosystem model is coupled with a one-dimensional mixed layer model. The mixed layer model has 20 layers in the vertical between the surface and a depth of $100 \mathrm{~m}$, with vertical resolution of $5 \mathrm{~m}$. The physical-biogeochemical model is applied to the location and period of SEEDS (from 18 to 31 July 2001 at $48.5^{\circ} \mathrm{N}, 165^{\circ} \mathrm{E}$ ), an 5 iron-enrichment experiment in the subarctic western North Pacific (Tsuda et al., 2003; Takeda and Tsuda, 2005). The model structure, forcing functions, and parameter values are similar as those described by Fujii et al. (2005). A few modifications to the model experimental design from Fujii et al. (2005) are carried out to directly compare the model results with the observations in the eight iron-enrichment experiments de10 scribed in de Baar et al. (2005). The MLD and the daily-averaged photosynthetically active radiation (PAR) in the mixed layer in a standard experiment are fixed at $12.5 \mathrm{~m}$ and $75.1\left[\mathrm{~W} \mathrm{~m}^{-2}\right]$ respectively, during the simulation period of 60 days.

In this model, the diatom growth rate is calculated as the product of the maximum growth rate, water temperature dependence $\left(Q_{10}\right.$ effect), light regulation, nutrient $\left(\mathrm{NO}_{3}\right.$, $15 \mathrm{NH}_{4}$ and $\left.\mathrm{Si}(\mathrm{OH})_{4}\right)$ controls, and diatom concentration, as follows:

$$
\begin{aligned}
& \text { Diatom total growth rate }=\underbrace{V_{\max L}}_{\text {Term } 1} \times \underbrace{\exp \left(k_{L} \times T\right)}_{\text {Term } 2} \\
& \times \underbrace{\min \left\{\frac{\left[\mathrm{NO}_{3}\right]}{\left[\mathrm{NO}_{3}\right]+\mathrm{K}_{\mathrm{NO}_{3 L}}} \exp \left(-\Psi_{L} \times\left[\mathrm{NH}_{4}\right]\right)+\frac{\left[\mathrm{NH}_{4}\right]}{\left[\mathrm{NH}_{4}\right]+\mathrm{K}_{\mathrm{NH}_{4 L}}}, \frac{\left[\mathrm{Si}(\mathrm{OH})_{4}\right]}{\left[\mathrm{Si}(\mathrm{OH})_{4}\right]+\mathrm{K}_{\mathrm{SiL}}}\right\}}_{\text {Term } 4} \\
& \times \underbrace{\left\{1-\exp \left(\frac{-\alpha \times \mathrm{PAR}}{V_{\max L}}\right)\right\}}_{\text {Term } 5} \times \underbrace{\text { [iam }}_{[\text {Diatom biomass }]},
\end{aligned}
$$

where $\mathrm{T}$ is the water temperature $\left[{ }^{\circ} \mathrm{C}\right], V_{\max L}$ is the maximum growth rate $\left[\mathrm{day}^{-1}\right.$ ], and $\alpha$ is the initial slope of the photosynthesis-irradiance ( $P$ vs. I) curve $\left[\mathrm{W}^{-1} \mathrm{~m}^{2}\right.$ day $\left.{ }^{-1}\right]$. See Table 2 in Fujii et al. (2005) for the other abbreviations. Following Fujii et al. (2005), the

\section{BGD}

4, 4411-4441, 2007

\section{Modeling iron-fertilization experiments}

M. Fujii and F. Chai

Title Page

Abstract

Introduction

Conclusions

Tables

References

Figures

14

-1

4

Back

Close

Full Screen / Esc

Printer-friendly Version

Interactive Discussion 
models, while trace nutrient iron is implicit in $V_{\max L}$ and $\alpha$ as explained below.

In this model, diatoms are set to be grazed on mainly by mesozooplankton and a small portion $(\sim 10 \%)$ by macrozooplankton. The grazing on diatoms by mesozooplankton, or the total grazing rate, is expressed as the product of the maximum grazing 5 rate, water temperature dependence $\left(Q_{10}\right.$ effect), and biomass of both diatoms and mesozooplankton, as follows:

Total grazing rate on diatoms by mesozooplankton $=G_{R \max P L} \times \exp \left(k_{G} \times T\right)$ $\times \max \{0,1-\exp (-\lambda \times[$ Diatom biomass $])\} \times[$ Mesozooplankton biomass].

In order to simulate the effects of iron enrichment in this model, the values of $V_{\max } L$ [day ${ }^{-1}$ ] $\alpha\left[\mathrm{W}^{-1} \mathrm{~m}^{2} \mathrm{day}^{-1}\right.$ ], and the chlorophyll-carbon ratio by weight for diatoms are set to increase linearly from Day 0 (the date on which the iron was infused into the surface water) to Day 3 , to be kept at the maxima (three times higher than the initial values) until Day 10, and to decrease linearly to the initial values at Day 20 (Fig. 2). Using a higher maximum specific growth rate for diatoms is equivalent to removing or greatly reducing all physiological limitations due to trace nutrients such as iron. By 15 keeping all other model parameters the same, including the grazing formulation, the effect of removing a physiological constraint on photosynthetic performance or growth can be distinguished from the effects of physical processes and grazing. Similar procedures have been used in previous modeling studies to investigate the effect and impact of iron fertilization on phytoplankton growth dynamics (Denman and Peña, 1999; Chai et al., 2002 and 2007; Fujii et al., 2005; Yoshie et al., 2005). Notice this merely simulates the role of iron in SEEDS, whereas a dedicated sensitivity analysis to iron is the subject of ongoing studies.

To investigate the effects on the phytoplankton community in response to different MLD and initial plankton conditions, we conducted several sets of model sensitivity studies (Table 1) in reference to realistic observed ranges (e.g. de Baar et al., 2005; Tsuda et al., 2007). The first set of experiments investigates the role of MLD, the maximum of which is fixed at 7.5 (Case 1-1), 12.5 (Case 1-2; standard case), 17.5
BGD

4, 4411-4441, 2007

\section{Modeling iron-fertilization experiments}

M. Fujii and F. Chai

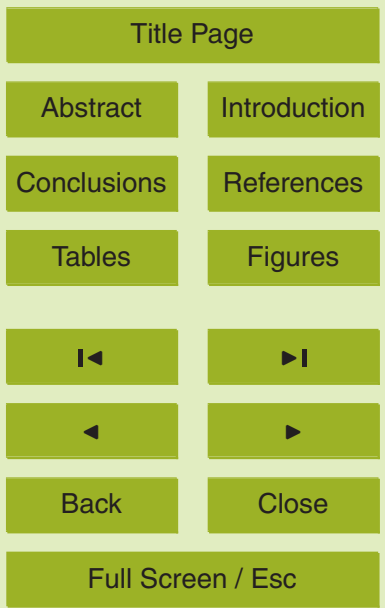

Printer-friendly Version

Interactive Discussion 
(Case 1-3), 22.5 (Case 1-4), 27.5 (Case 1-5), 47.5 (Case 1-6), and $72.5 \mathrm{~m}$ (Case 17) (Experiment 1). The second set of experiments studied the role of initial diatom biomass on Day 0, which was set at 0.001 (Case 2-1), 0.01 (Case 2-2), 0.1 (Case 2-3), 1 (Case 2-4; standard case), 10 (Case 2-5), 100 (Case 2-6), and 1000 (Case

5 2-7) times the standard initial condition used in Fujii et al. (2005) (Experiment 2). The initial mesozooplankton biomass on Day 0 was set at 0.01 (Case 3-1), 0.1 (Case 3-2), 1 (Case 3-3; standard case), 5 (Case 3-4), 10 (Case 3-5), 20 (Case 3-6), and 30 (Case 3-7) times the standard value as used in Fujii et al. (2005) (Experiment 3). Additional experiments 4, 5 and 6 (see Table 1) were done with similar variations in the initial - biomass of non-diatom small phytoplankton PS (Experiment 4), microzooplankton ZS (Experiment 5), and predatory macrozooplankton ZP (Experiment 6), respectively.

\section{Results and discussion}

We evaluated the model performance using the SEEDS results, which served as a reference state. In comparison with SEEDS observations, the model results in the 15 standard case (Cases 1-2, 2-4, and 3-3; they are identical) reproduce the observations reasonably well after the iron infusion, i.e., a rapid increase in surface chlorophyll and decreases in surface nutrients and $\mathrm{pCO}_{2 \text { sea }}$ (black solid lines in Fig. 3). These changes are caused by a diatom bloom stimulated by the iron infusion. A detailed analysis of the standard case was presented in the papers by Fujii et al. (2005) and Yoshie et 20 al. (2005).

\subsection{Biogeochemical responses to mixed layer depth}

In Experiment 1, the water temperature is uniform in the mixed layer and decreases with the increase of MLD, from $9.3^{\circ} \mathrm{C}$ in Case $1-1(M L D=7.5 \mathrm{~m})$ to $4.3^{\circ} \mathrm{C}$ in Case 1-7 $(M L D=72.5 \mathrm{~m})($ Fig. 4a). The water temperature in the mixed layer shows an inverse 25 relationship with the MLD $\left(R^{2}=0.97\right.$; Fig. $\left.4 \mathrm{~b}\right)$. The mixed-layer-mean PAR also de-

\section{BGD}

4, 4411-4441, 2007

\section{Modeling iron-fertilization experiments}

M. Fujii and F. Chai

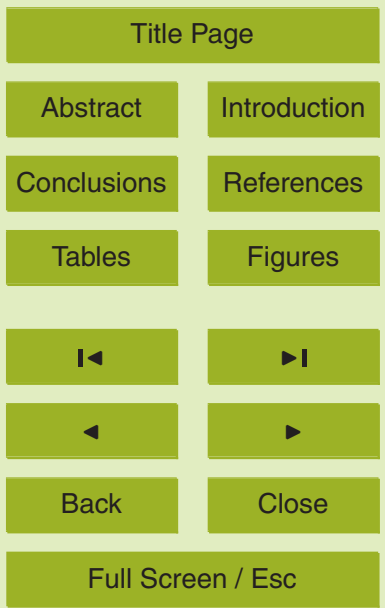

Printer-friendly Version

Interactive Discussion 
creases with the increase of MLD, from $18.0\left[\mathrm{~W} \mathrm{~m}^{-2}\right]$ in Case $1-1$ to $9.3\left[\mathrm{~W} \mathrm{~m}^{-2}\right]$ in Case 1-7, and is inversely correlated with the $\operatorname{MLD}\left(R^{2}=0.79\right.$; Fig. $\left.4 \mathrm{C}\right)$.

The modeled iron-induced biogeochemical responses, namely the rapid increase in surface chlorophyll and decreases in surface nutrients and $\mathrm{pCO}_{2 \text { sea }}$, occur earlier and 5 are larger with shallower MLD cases (Fig. 3a). The maximum surface chlorophyll appears on Day 11, 12, 13, 13, 14, 16, and 18 in Cases 1-1, 1-2, 1-3, 1-4, 1-5, 1-6, and 1-7, respectively. The maximum surface chlorophyll, and the maximum differences between inside and outside the iron patch for surface silicate $\left(\triangle \mathrm{Si}(\mathrm{OH})_{4}\right)$, surface DIC $(\triangle \mathrm{DIC}), \mathrm{pCO}_{2 \text { sea }}\left(\Delta \mathrm{pCO}_{2 \text { sea }}\right)$, net community production above $100 \mathrm{~m}$ depth $(\triangle \mathrm{NCP})$, 10 and export production at $100 \mathrm{~m}$ depth $(\triangle \mathrm{EP})$, are plotted in Fig. 5-1. The model results show a striking and significant inverse relationship $\left(R^{2}>0.94\right)$ between each variable and the MLD, consistent with the observations from the eight iron-enrichment experiments (de Baar et al., 2005). This suggests that the inverse relationship between the MLD and the iron-induced biogeochemical responses is a robust feature, which has 15 been documented both in this model of SEEDS and in the other observations (de Baar et al., 2005).

While most of the variables have their peaks in Case 1-1 (MLD $=7.5 \mathrm{~m})$, the modeled $\triangle E P$ has its peak of 1908.8 [mgC m$^{-2}$ day $^{-1}$ ] in Case 1-2 (MLD=12.5 m) (Fig. 5-1f). This is due to greater decomposition of the particulate organic carbon in the MLD in 20 Case 1-1, resulting from higher water temperature (Fig. 4a). Previous studies show that the e-ratio is inversely correlated with the water temperature (e.g., Laws et al., 2000; Fujii et al., 2005). As the surface water temperature was much more diverse among the eight iron-enrichment experiments $\left(-0.5\right.$ through $25.2^{\circ} \mathrm{C}$; de Baar et al., 2005) than in this study (4.3 through $9.3^{\circ} \mathrm{C}$; Fig. $\left.4 \mathrm{~b}\right)$ and there is no clear correlation 25 between the observed MLD and surface water temperature $\left(R^{2}=0.32\right.$; Fig. 6$)$, the $\Delta \mathrm{EP}$ in the real iron-enrichment experiments is unlikely to have an inverse relationship with the MLD. Export production is an essential variable for assessing the efficiency of the oceanic carbon uptake by iron-enrichment experiments, although the export of carbon into deeper waters is difficult to estimate and, to date, has been proven quite modest

BGD

4, 4411-4441, 2007

\section{Modeling iron-fertilization experiments}

M. Fujii and F. Chai

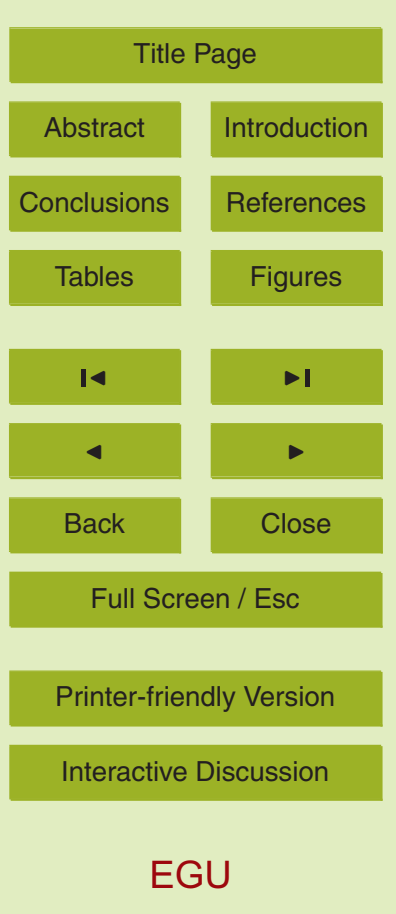


in only two iron experiments (de Baar et al., 2005).

We examined the predominant factors that cause the notable inverse relationship between the maximum surface chlorophyll and the MLD, by comparing the modeled magnitude of terms in Eq. (1). Figure 7 shows the vertical profiles of Terms 1, 2, 53,4 , and 5 in Eq. (1), the diatom specific growth rate (equivalent to the product of Terms $1,2,3$, and 4), and the diatom total growth rate (equivalent to the product of the diatom specific growth rate and Term 5), on the date when the maximum surface chlorophyll appears. The maximum diatom growth rate (Term 1; Fig. 7a) is higher in Case 1-1 $(\mathrm{MLD}=7.5 \mathrm{~m})$ than in Case 1-7 $(\mathrm{MLD}=72.5 \mathrm{~m})$ by a factor of 1.9 , because 10 the maximum surface chlorophyll appears earlier in shallower MLD cases (Figs. 2 and 3a). The temperature dependence term (Term 2; Fig. 7b) is larger in Case 1-1 than in Case 1-7 by a factor of 1.2, due to higher water temperatures in shallower MLD cases (Fig. 4a). The nutrient limitation (Term 3; Fig. 7c), by contrast, is weaker in Case 1-7 than in Case 1-1 by a factor of 1.1 due to higher nutrient concentrations in deeper MLD cases (Fig. 3a). Interestingly, the light limitation (Term 4; Fig. 7d) at each depth is stronger in shallower MLD cases, because self-shading by the more abundant phytoplankton diminishes the available light below. The light limitation in the surface water is slightly stronger in Case 1-1 than in Case 1-7 but only by a factor of 1.1. As a result, the diatom specific growth rate (Fig. 7e) is higher by a factor of 1.7 at the surface, but it is lower in the subsurface layers, in Case 1-1 than in Case 1-7.

The most significant difference among the MLD cases is the diatom biomass (Term 5; Fig. 7f). The diatom biomass is uniform within the mixed layer because of vertical mixing, and it is larger in Case 1-1 than in Case 1-7 by a factor of 7.1. Also the surface maximum chlorophyll differs between cases by a factor of 10.0 (Fig. 5-1a). Consequently, the diatom total growth rate at the surface (Fig. $7 \mathrm{~g}$ ) is much higher in Case 1-1 than in Case 1-7 by a factor of 12.3, primarily due to the larger diatom biomass. The diatom total growth rate decreases exponentially with depth in any case, but more rapidly in shallower MLD cases because of rapid decreases in both diatom specific growth rate and diatom biomass with depth. Therefore, depth integration of the

BGD

4, 4411-4441, 2007

\section{Modeling iron-fertilization experiments}

M. Fujii and F. Chai

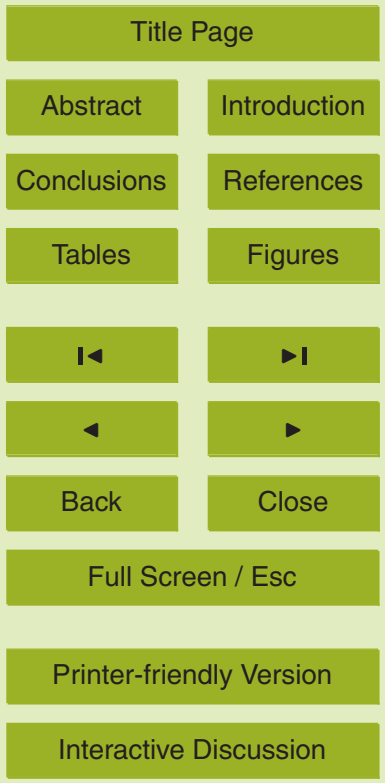

EGU 
diatom total growth rate, namely the net community production, partly compensates the advance effects of a deep MLD, decreasing the differences in responses among the cases to a factor of 4.4 (Fig. 5-1e; de Baar et al., 2005).

BGD

4, 4411-4441, 2007

\subsection{Biogeochemical responses to initial plankton conditions}

5 With different initial diatom biomass (Experiment 2), the iron-induced diatom bloom occurs earlier and is larger with higher initial diatom concentration (Fig. 8-1c). The decrease of $\mathrm{Si}(\mathrm{OH})_{4}$ (Fig. 3b) is weakest with the lowest initial diatom biomass (Case 2-1; 0.001 times the standard initial diatom biomass). With different initial mesozooplankton biomasses (Experiment 3), the iron-induced diatom bloom occurs earlier and is larger with lower initial mesozooplankton biomass (Fig. 8-2c). The surface chlorophyll increases by a factor of 75 with lower initial mesozooplankton biomass (Cases 3-1 and 3-2; 0.01 and 0.1 times the standard initial mesozooplankton biomass; Fig. 3c), but its increase is only by a factor of 30 with the highest initial mesozooplankton biomass (Case 3-7; 30 times the standard initial mesozooplankton biomass; Fig. 3c). The decrease of $\mathrm{Si}(\mathrm{OH})_{4}($ Fig. 3c) is weakest with the highest initial mesozooplankton biomass (Case 3-7).

The iron-induced diatom bloom is triggered by a rapid increase in the diatom specific growth rate (equivalent to diatom total growth rate divided by diatom biomass; Eq. (1) and Figs. 8-1a and 8-2a). The diatom specific growth rate increases from 0.6 [day $^{-1}$ ] 20 on Day 0 to up to 1.9 [day $^{-1}$ ] on about Day 5 in all cases, which reflects the effects of iron enrichment on diatom growth. The diatom specific growth rate returns to the initial level of 0.6 [day $^{-1}$ ] after termination of the iron enrichment. This result indicates that iron concentration controls diatom specific growth rates regardless of initial plankton biomass.

25 Compared to the diatom specific growth rate, specific grazing rate on diatoms by mesozooplankton (total grazing rate on diatoms by mesozooplankton divided by mesozooplankton biomass; Eq. (2)) is different among the cases (Figs. 8-1b and 8-2b). The specific grazing rate increases rapidly from very low values to close to 0.8 [day $^{-1}$ ] in all

\section{Modeling iron-fertilization experiments}

M. Fujii and F. Chai

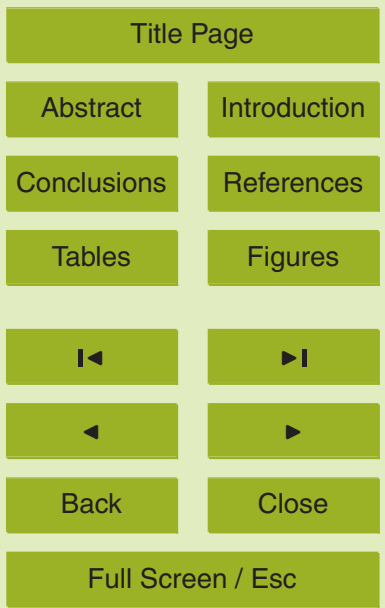

Printer-friendly Version

Interactive Discussion 
cases. The lower specific grazing rate at the first phase of simulation (from Day 0 to Day 10) in Cases 2-1 and 2-2 (Fig. 8-1b) is initially due to lower diatom concentration. The slow accumulation of diatom biomass (Cases 2-1 and 2-2; Fig. 8-1c) results in a delayed peak of the specific grazing rate, which is determined by diatom concentration. 5 On the other hand, higher initial mesozooplankton biomass (Cases 3-6 and 3-7) results in lower diatom biomass (Fig. 8-2c) and a lower specific grazing rate of mesozooplankton (Fig. 8-2b) during the first phase of iron infusion, which is initially due to higher grazing pressure on diatoms. With lower initial mesozooplankton biomass (Cases 3-1 and 3-2), by contrast, diatoms at the first phase can escape from high grazing pres10 sure and produce a stronger bloom (Fig. 8-2c). The high biomass of diatoms provides an adequate food supply for mesozooplankton, which results in an earlier peak of the specific grazing rate and mesozooplankton biomass (Fig. 8-2b, d).

The time series of the diatom total growth rate is similar to that of the diatom concentration in both Experiments 2 and 3 (Figs. 8-1c, e and 8-2c, e). The maximum diatom total growth rate appears earlier and higher with higher initial diatom concentration (Fig. 8-1e). For the different cases with initial mesozooplankton biomass, the diatom total growth rate is higher and reaches its maximum earlier with lower initial mesozooplankton biomass (Cases 3-1 and 3-2; Fig. 8-2 e).

In Experiment 2, the maximum total grazing rate on diatoms by mesozooplankton $20 \quad\left(0.24-0.30\left[\mathrm{day}^{-1}\right]\right)$ is similar among the cases, but the timing of the peak is earlier with higher initial diatom concentrations (Fig. 8-1f). The delayed peak of grazing on diatoms with lower initial diatom biomass (Cases 2-1 and 2-2) is due to slower accumulation of diatom biomass (Fig. 8-1c, f). In Experiment 3, however, the total grazing rate varies substantially not only in timing but also in magnitude (Fig. 8-2f). With the highest initial mesozooplankton biomass (Cases 3-7), the total grazing rate on diatoms is low and peaks on Day 45. This is because of the slower buildup of diatom biomass (Fig. 8-2c). It seems that two cases with intermediate initial mesozooplankton biomass (Cases 3-4 and 3-5) produce the highest total grazing rate on diatoms, which results from high diatom and mesozooplankton biomass (Fig. 8-2c, d, f). The intermediate initial

\section{BGD}

4, 4411-4441, 2007

\section{Modeling iron-fertilization experiments}

M. Fujii and F. Chai

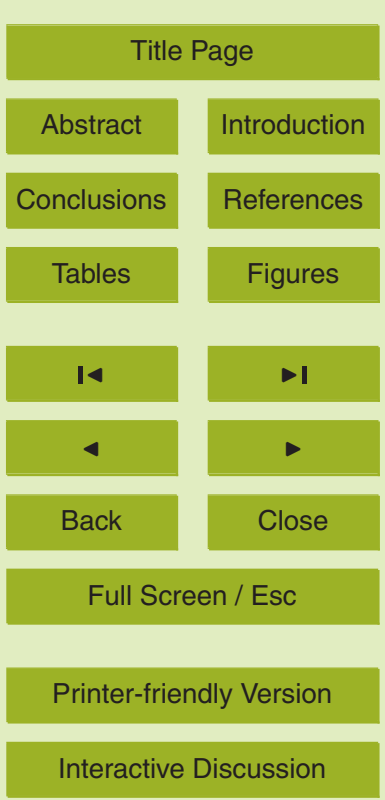

EGU 
mesozooplankton biomass could yield relatively high biomass for both diatoms and mesozooplankton, suggesting strong trophic links at either intermediate grazer density. This finding is in good agreement with fundamental theory in revealing that on foodweb dynamics away from equilibrium, weak to intermediate strength links are important 5 in promoting community persistence and stability because weak links act to dampen oscillations between consumers and resources (e.g. McCann et al., 1998; Van der Meer, 2004). Therefore, the initial level of mesozooplankton biomass, i.e., the condition of higher tropic levels at the time of iron infusion, plays an important role in determining the intensity of the iron-induced diatom bloom (Tsuda et al., 2007) and total increase 10 of mesozooplankton.

\subsection{Relative impacts of physical and biological conditions}

The maximum surface chlorophyll, $\Delta \mathrm{NO}_{3}, \Delta \mathrm{Si}(\mathrm{OH})_{4}, \Delta \mathrm{DIC}, \Delta \mathrm{pCO}_{2 \text { sea }}, \Delta \mathrm{NCP}$, and $\triangle E P$ are compared among Experiments 1, 2, and 3 (Table 2; Figs. 5-1 and 5-2). It is interesting that the magnitude of the diatom bloom in terms of the surface maximum 5 chlorophyll (Fig. 5-2a) differs only by a factor of 2.9 in Experiment 2, although the initial diatom biomass differs by an order of $10^{6}$. For most of the variables, the fluctuation is the greatest in Experiment 1 (Table 2). For the $\triangle \mathrm{NCP}$ and $\triangle \mathrm{EP}$, however, the fluctuation range is much larger in Experiment 3 than in Experiment 1. Therefore, this modeling study suggests that the MLD is generally the most predominant factor, but the initial mesozooplankton biomass is also very crucial, especially in controlling the column integrated variables such as net community production and export production.

We have also examined the effects of the iron enrichments on the phytoplankton community in response to different initial non-diatom small phytoplankton (Experiment 4), microzooplankton (Experiment 5), and predatory macrozooplankton (Experiment 6) conditions, by changing from 0.001 to 1000 times (Experiment 4) and from 0.01 to 30 times (Experiments 5 and 6) the standard initial condition used in Fujii et al. (2005), respectively (Tables 1 and 2). The profile of each variable vs. initial phytoplankton biomass in Experiment 4 is a mirror image of that in Experiment 2 (Fig. 5-2), showing

\section{BGD}

4, 4411-4441, 2007

\section{Modeling iron-fertilization experiments}

M. Fujii and F. Chai

Title Page

Abstract

Introduction

Conclusions

Tables

References

Figures

14

-1

4

Back

Close

Full Screen / Esc

Printer-friendly Version

Interactive Discussion 
that the increase in the initial diatom biomass corresponds to the decrease in the initial non-diatom small phytoplankton biomass. The fluctuation is mostly smaller in Experiment 4 than in Experiment 2 except for $\Delta \mathrm{NO}_{3}$ (Table 2), indicating that the modeled $\Delta \mathrm{NO}_{3}$ is more sensitive to the initial non-diatom small phytoplankton than to the initial 5 diatom biomass. The overall model results (Table 2) show that the plankton ecosystem is not very sensitive to variations in initial non-diatom small phytoplankton (Experiment 4 ), initial microzooplankton (Experiment 5) or initial predatory macrozooplankton (Experiment 6). Therefore the findings of the latter Experiments 4, 5 and 6 will not further be discussed or shown in graphics.

\section{Concluding remarks}

Using a marine ecosystem model, we examined the influence of initial plankton conditions and mixed layer depth on the biogeochemistry of HNLC regions. The modeled responses to the same iron enhancement treatment differed dramatically according to different mixed layer depth. The observed inverse relationship between the maximum 15 surface chlorophyll and mixed layer depth of eight different in situ experiments, is well simulated by variation of mixed layer depth for just one such experiment, even though the other conditions such as sea surface irradiance are set similarly among the simulations, and even though the model is applied to merely one in-situ iron-enrichment experiment (SEEDS). This shows that the mixed layer depth is the predominant factor in controlling iron-induced biogeochemical responses, as mentioned by de Baar et al. (2005). The significant difference in the maximum surface chlorophyll with the mixed layer depth is primarily caused by diatom concentration in the mixed layer, which is determined by vertical mixing. Other factors that result from the change of mixed layer depth, such as temperature, light and nutrients, play lesser roles on the formation of the surface chlorophyll maximum.

The initial biomass of mesozooplankton is also important in determining the ironinduced biogeochemical responses. Higher initial mesozooplankton biomass yields

\section{BGD}

4, 4411-4441, 2007

\section{Modeling iron-fertilization experiments}

M. Fujii and F. Chai

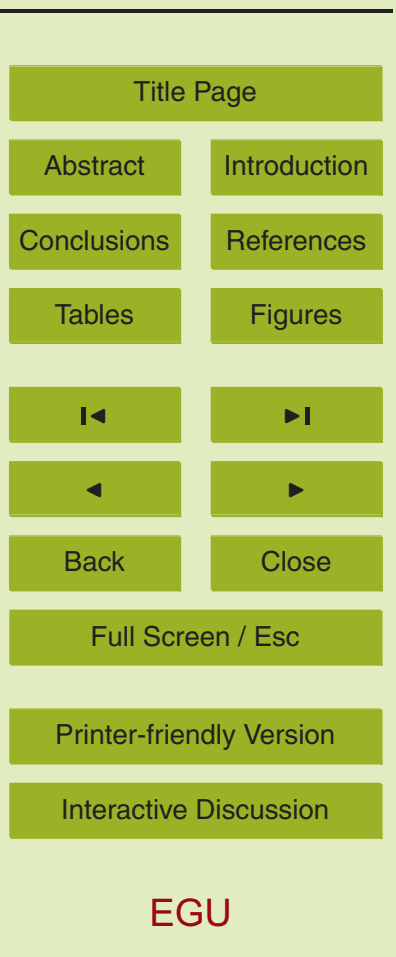


high grazing pressure on diatoms, which results in less accumulation of diatom biomass during the iron enrichment period. Although the influences are less significant than those of the mixed layer depth in most variables, the column-integrated net community production and export production are more strongly determined by the ini-

5 tial mesozooplankton biomass. As export production is a key variable for assessing the efficiency of the oceanic carbon uptake by the iron experiments, the importance of grazing to the outcome of iron experiments should be more worthy of attention. Also we need to keep in mind that efficiency could be evaluated using different variables, i.e., with surface values vs. column-integrated values.

10 The initial biomass of diatoms is also important but is not as crucial as the mixed layer depth and the initial mesozooplankton biomass in determining the overall plankton community response to the iron enrichments. Diatom blooms occur with any initial diatom concentrations, due to the very fast diatom growth rates stimulated by iron addition. But the iron-induced diatom growth may not result in the accumulation of diatom biomass under the high grazing pressure imposed by extremely high initial mesozooplankton biomass.

This modeling study suggests that in addition to the mixed layer depth, initial plankton biomass, especially principal grazers on diatoms, is a crucial factor in the response of the phytoplankton community to iron enrichments. The modeling result may account for the different biological responses of SEEDS versus SEEDS II, which were conducted in the same location and at the same season of the year. The notably higher surface chlorophyll during SEEDS than during SEEDS II may primarily be due to the significantly 3 to 5 times lower initial mesozooplankton biomass at the beginning of SEEDS compared to SEEDS II, because other factors such as the initial diatom biomass and 25 the physical and chemical environmental conditions were very similar (Tsuda et al., 2007). The result from this study is also consistent with the hypothesis that phytoplankton bloom development in the Southern Ocean is highly sensitive to both physical and biological parameters that determine vertical mixing and phytoplankton loss rates mainly due to grazing pressure (Mitchell et al., 1991; Sakshaug et al., 1991; Lancelot et

BGD

4, 4411-4441, 2007

\section{Modeling iron-fertilization experiments}

M. Fujii and F. Chai

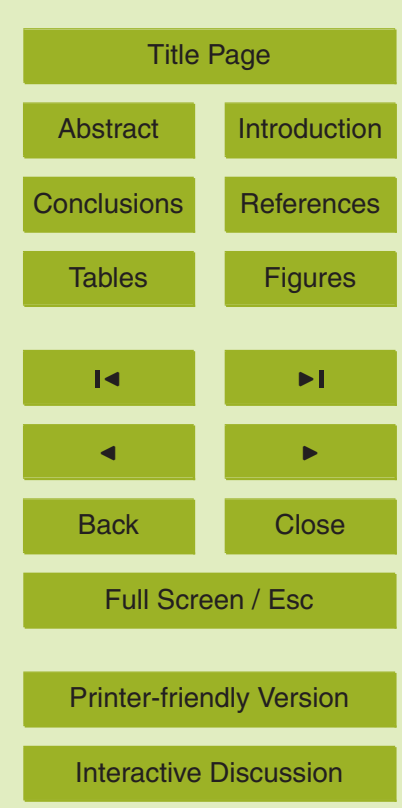

EGU 
al., 1993). This suggests that the modeling results from this study could be applied to other HNLC regions and the factors affecting the potential outcome of iron-fertilization in these regions. The initial state of the plankton community, along with physical and chemical environmental conditions, should be taken into account when designing fu-

Acknowledgements. This research was supported by a National Science Foundation grant (OCE-0137272) to F. Chai. M. Fujii was supported by MEXT through Special Coordination Funds for Promoting Sciences and Technology.

\section{References}

Bance, K.: Does iron really limit phytoplankton production in the offshore subarctic Pacific?, Limnol. Oceanogr., 35, 772-775, 1990.

Boyd, P. W., Watson, A. J., Law, C. S., et al.: A mesoscale phytoplankton bloom in the polar Southern Ocean stimulated by iron fertilization, Nature, 407, 695-702, 2000.

Boyd, P. W., Law, C. S., Wong, C. S., et al.: The decline and fate of an iron-induced subarctic phytoplankton bloom, Nature, 428, 549-553, 2004.

Chai, F., Dugdale, R. C., Peng, T.-H., Wilkerson, F. P., and Barber, R. T.: One-dimensional ecosystem model of the equatorial Pacific upwelling system. Part I: model development and silicon and nitrogen cycle, Deep-Sea Res. Part II, 49, 2713-2745, 2002.

Chai, F., Jiang, M.-S., Chao, Y., Dugdale, R. C., Chavez, F., and Barber, R. T.: Modeling responses of diatom productivity and biogenic silica export to iron enrichment in the equatorial Pacific ocean, Global Biogeochem. Cy., 21, GB3S90, doi:10.1029/2006GB002804, 2007.

Coale, K. H., Johnson, K. S., Fitzwater, S. E., et al.: A massive phytoplankton bloom induced by an ecosystem-scale iron fertilization experiment in the equatorial Pacific Ocean, Nature, 383, 495-501, 1996.

25 Coale, K. H., Johnson, K. S., Chavez, F. P., et al.: Southern Ocean iron enrichment experiment: Carbon cycling in high- and low-Si waters, Science, 304, 408-414, 2004.

de Baar, H. J. W., Boyd, P. W., Coale, K. H., et al.: Synthesis of iron fertilization experiments: From the iron age in the age of enlightenment, J. Geophys. Res., 110, C09S16, doi:10.1029/2004JC002601, 2005.
BGD

4, 4411-4441, 2007

\section{Modeling iron-fertilization experiments}

M. Fujii and F. Chai

\section{Title Page}

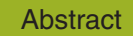

Introduction

Conclusions

References

Tables

Figures

14

4

Back

Close

\section{Full Screen / Esc}

Printer-friendly Version

Interactive Discussion 
Denman, K. L. and Peña, M. A.: A coupled 1-D biological/physical model of the northeast subarctic Pacific Ocean with iron limitation, Deep-Sea Res. Part II, 46, 2877-2908, 1999.

Fujii, M., Nojiri, Y. Yamanaka, Y., and Kishi, M. J.: A one-dimensional ecosystem model applied to time series station KNOT, Deep-Sea Res. Part II, 49, 5441-5461, 2002.

5 Fujii, M., Yoshie, N., Yamanaka, Y., and Chai, F.: Simulated biogeochemical responses to iron enrichments in three high nutrient, low chlorophyll (HNLC) regions, Prog. Oceanogr., 64, 307-324, doi:10.1016/j.pocean.2005.02.017, 2005.

Gervais, F., Riebesell, U., and Gorbunov, M. Y.: Changes in primary productivity and chlorophyll a in response to iron fertilization in the southern Polar Frontal Zone, Limnol. Oceanogr., 47, $10 \quad$ 1324-1335, 2002.

Hall, J. A. and Safi, K.: The impact of in situ Fe fertilization on the microbial food web in the Southern Ocean, Deep-Sea Res. Part II, 48, 2591-2613, 2001.

Hannon, E., Boyd, P. W., Silvoso, M., and Lancelot, C: Modeling the bloom evolution and carbon flows during SOIREE: Implications for future in situ iron-enrichments in the Southern Ocean,

15 Deep-Sea Res. Part II, 48, 2745-2773, 2001.

Lancelot, C., Mathot, S., Veth, C., and de Baar, H. J. W.: Factors controlling phytoplankton ice-edge blooms in the marginal ice-zone of the northwestern Weddell Sea during sea ice retreat 1988: field observations and mathematical modeling, Polar Biol., 13, 377-387, 1993.

Landry, M. R., Constantinou, J., Latasa, M., Brown, S. L., Bidigare, R. R., and Ondrusek, $20 \quad$ M. E.: Biological response to iron fertilization in the eastern equatorial Pacific (IronEx II). III. Dynamics of phytoplankton growth and microzooplankton grazing, Mar. Ecol. Prog. Ser., 201, 57-72, 2000a.

Landry, M. R., Ondrusek, M. E., Tanner, S. J., Brown, S. L., Constantinou, J., Bidigare, R. R., Coale, K. H., and Fitzwater, S.: Biological response to iron fertilization in the eastern equatorial Pacific (IronEx II). I. Microplankton community abundances and biomass, Mar. Ecol. Prog. Ser., 201, 27-42, 2000b.

Laws, E. A., Falkowski, P. G., Smith Jr., W. O., Ducklow, H., and McCarthy, J. J.: Temperature effects on export production in the open ocean, Global Biogeochem. Cy., 14, 1231-1246, 2000.

30 Martin, J. H.: Glacial-interglacial $\mathrm{CO}_{2}$ change: the iron hypothesis, Paleoceanogr., 5, 1-13, 1990.

Martin, J. H. and Fitzwater, S. E.: Iron deficiency limits phytoplankton growth in the north-east Pacific subarctic, Nature, 331, 341-343, 1988.

BGD

$4,4411-4441,2007$

\section{Modeling \\ iron-fertilization \\ experiments}

M. Fujii and F. Chai

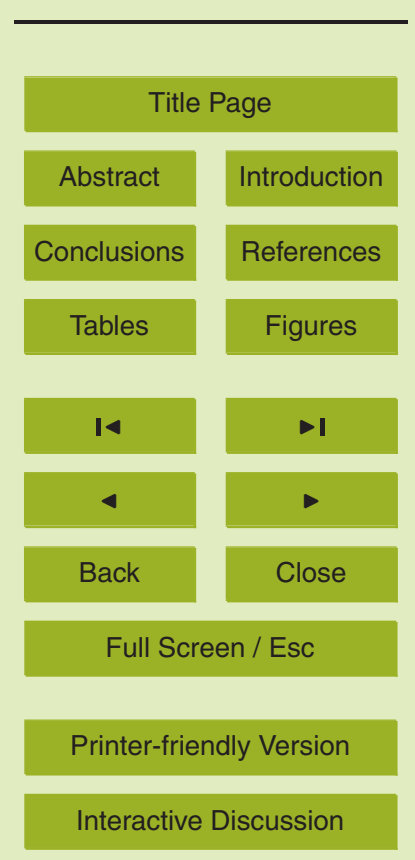

EGU 
McCann, K., Hastings, A., and Huxel, G. R.: Weak trophic interactions and the balance of nature, Nature, 395, 794-798, 1998.

Mitchell, B. G., Brody, E. A., Holm-Hansen, O., McClain, C., and Bishop, J.: Light limitation of phytoplankton biomass and macronutrient utilization in the Southern Ocean, Limnol.

5 Oceanogr., 36(8), 1662-1677, 1991.

Redfield. A.C., B.A Ketchum, B. A., and Richards, F. A.: The influence of organisms on the composition of seawater, in: The Sea, edited by: Hill, M. H., Wiley, New York, 26-77, 1963.

Rollwagen Bollens, G. C. and Landry, M. R.: Biological response to iron fertilization in the eastern equatorial Pacific (IronEx II). II. Mesozooplankton abundance, biomass, depth distri-

10 bution and grazing, Mar. Ecol. Prog. Ser., 201, 43-56, 2000.

Saito, H., Ota, T., Suzuki, K., Nishioka, J., and Tsuda, A.: Role of heterotrophic dinoflagellate Gyrodinium sp. in the fate of an iron induced diatom bloom, Geophys. Res. Lett., 33, L09602, doi:10.1029/2005GL025366, 2006.

Saito, H., Suzuki, K., Hinuma, A., et al.: Responses of microzooplankton to in situ iron 15 fertilization in the western subarctic Pacifcic (SEEDS), Prog. Oceanogr., 64, 223-236, doi:10.1016/j.pocean.2005.02.010, 2005.

Sakshaug, E., Slagstad, D., and Holm-Hansen, O.: Factors controlling the development of phytoplankton blooms in the Antarctic Ocean - a mathematical model, Mar. Chem., 35, 259271, 1991.

20 Suzuki, K., Hinuma, A., Saito, H., Kiyosawa, H., Liu, H., Saino, T., and Tsuda, A.: Responses of phytoplankton and heterotropic bacteria in the northwest subarctic Pacific to in situ iron fertilization as estimated by HPLC pigment analysis and flow cytometry, Prog. Oceanogr., 64, doi:10.1016/j.pocean.2005.02.007, 2005.

Takeda, S. and Tsuda, A.: An in situ iron-enrichment experiment in the western sub25 arctic Pacific (SEEDS): Introduction and summary, Prog. Oceanogr., 64, 95-109, doi:10.1016/j.pocean.2005.02.004, 2005.

Tsuda, A., Takeda, S., Saito, H., et al.: Evidence for the grazing hypothesis: Grazing reduces phytoplankton responses of the HNLC ecosystem to iron enrichment in the western subarctic Pacific (SEEDS II), J. Oceanogr., 63, 983-984, 2007.

so Tsuda, A., Takeda, S., Saito, H., et al.: A mesoscale iron enrichment in the western subarctic Pacific induces a large centric diatom bloom, Science, 300, 958-961, 2003.

Van der Meer, J.: Coupled oscillations in food webs: Balancing competition and mutualism in simple ecological models, The American Naturalist, 163(6), 857-867, 2004.

BGD

4, 4411-4441, 2007

\section{Modeling \\ iron-fertilization \\ experiments}

M. Fujii and F. Chai

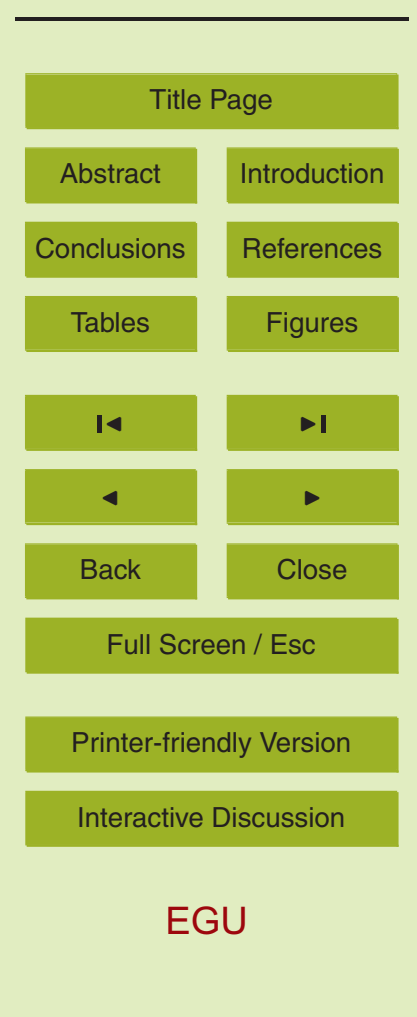


Yamanaka, Y., Yoshie, N., Fujii, M., Aita, M. N., and Kishi, M. J.: An ecosystem model coupled with Nitrogen-Silicon-Carbon cycles applied to Station A7 in the Northwestern Pacific, J. Oceanogr., 60, 227-241, 2004.

Yoshie, N., Fujii, M., and Yamanaka, Y.: Ecosystem changes with the iron fertilization in the 5 western North Pacific simulated by a one-dimensional ecosystem model, Prog. Oceanogr., 64, 283-306, doi:10.1016/j.pocean.2005.02.014, 2005.

\section{BGD}

4, 4411-4441, 2007

\section{Modeling iron-fertilization experiments}

M. Fujii and F. Chai

\section{Title Page}

Abstract Introduction

Conclusions References

Tables Figures

14

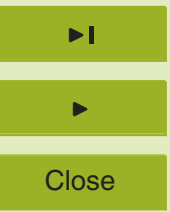

Back

Full Screen / Esc

Printer-friendly Version

Interactive Discussion 


\section{BGD}

4, 4411-4441, 2007

Table 1. Model experimental design. Case numbers are shown in parentheses below the given fluctuation range. Cases 1-2, 2-4, 3-3, 4-4, 5-3, and 6-3 in bold print are the standard experiment (they are identical). Variations of Mixed Layer Depth MLD (Experiment 1), initial diatom biomass PL (Experiment 2) and initial mesozooplankton biomass ZL (Experiment 3) have been shown to be far more significant than variations of initial non-diatom small phytoplankton biomass PS (Experiment 4), initial microzooplantkon biomass ZS (Experiment 5) and initial predatory macrozooplankton biomass ZP (Experiment 6).

\begin{tabular}{|c|c|c|c|c|c|c|c|c|c|}
\hline \multirow{2}{*}{$\begin{array}{l}\text { Experiment } \\
\text { number }\end{array}$} & \multirow{2}{*}{$\begin{array}{l}\text { Changing parameter [unit] } \\
\text { Mixed Layer Depth [m] }\end{array}$} & \multirow{2}{*}{$\begin{array}{l}\text { Symbol } \\
\text { MLD }\end{array}$} & \multicolumn{7}{|c|}{ Fluctuation range } \\
\hline & & & $\begin{array}{l}7.5 \\
(1-1)\end{array}$ & $\begin{array}{l}12.5 \\
(1-2)\end{array}$ & $\begin{array}{l}17.5 \\
(1-3)\end{array}$ & $\begin{array}{l}22.5 \\
(1-4)\end{array}$ & $\begin{array}{l}27.5 \\
(1-5)\end{array}$ & $\begin{array}{l}47.5 \\
(1-6)\end{array}$ & $\begin{array}{l}72.5 \\
(1-7)\end{array}$ \\
\hline 2 & Initial diatom biomass $\left[\mathrm{mmol} \mathrm{m}^{-3}\right]$ & $\mathrm{PL}$ & $\begin{array}{l}0.001 \times \\
(2-1)\end{array}$ & $\begin{array}{l}0.01 \times \\
(2-2)\end{array}$ & $\begin{array}{l}0.1 \times \\
(2-3)\end{array}$ & $\begin{array}{l}1 \times \\
(2-4)\end{array}$ & $\begin{array}{l}10 x \\
(2-5)\end{array}$ & $\begin{array}{l}100 x \\
(2-6)\end{array}$ & $\begin{array}{l}1000 \times \\
(2-7)\end{array}$ \\
\hline 3 & $\begin{array}{l}\text { Initial mesozooplankton biomass } \\
{\left[\mathrm{mmol} \mathrm{m}^{-3}\right]}\end{array}$ & ZL & $\begin{array}{l}0.01 \times \\
(3-1)\end{array}$ & $\begin{array}{l}0.1 \times \\
(3-2)\end{array}$ & $\begin{array}{l}1 \times \\
(3-3)\end{array}$ & $\begin{array}{l}5 \times \\
(3-4)\end{array}$ & $\begin{array}{l}10 x \\
(3-5)\end{array}$ & $\begin{array}{l}20 \times \\
(3-6)\end{array}$ & $\begin{array}{l}30 x \\
(3-7)\end{array}$ \\
\hline 4 & $\begin{array}{l}\text { Initial non-diatom small } \\
\text { phytoplankton biomass }\left[\mathrm{mmol} \mathrm{m}^{-3}\right]\end{array}$ & PS & $\begin{array}{l}0.001 \times \\
(4-1)\end{array}$ & $\begin{array}{l}0.01 \times \\
(4-2)\end{array}$ & $\begin{array}{l}0.1 \times \\
(4-3)\end{array}$ & $\begin{array}{l}1 \times \\
(4-4)\end{array}$ & $\begin{array}{l}10 x \\
(4-5)\end{array}$ & $\begin{array}{l}100 x \\
(4-6)\end{array}$ & $\begin{array}{l}1000 \times \\
(4-7)\end{array}$ \\
\hline 5 & $\begin{array}{l}\text { Initial microzooplankton biomass } \\
{\left[\mathrm{mmol} \mathrm{m}^{-3}\right]}\end{array}$ & ZS & $\begin{array}{l}0.01 \times \\
(5-1)\end{array}$ & $\begin{array}{l}0.1 \times \\
(5-2)\end{array}$ & $\begin{array}{l}1 \times \\
(5-3)\end{array}$ & $\begin{array}{l}5 \times \\
(5-4)\end{array}$ & $\begin{array}{l}10 x \\
(5-5)\end{array}$ & $\begin{array}{l}20 \times \\
(5-6)\end{array}$ & $\begin{array}{l}30 x \\
(5-7)\end{array}$ \\
\hline 6 & $\begin{array}{l}\text { Initial predatory macrozooplankton } \\
\text { biomass }\left[\mathrm{mmol} \mathrm{m}^{-3}\right]\end{array}$ & ZP & $\begin{array}{l}0.01 \times \\
(6-1)\end{array}$ & $\begin{array}{l}0.1 \times \\
(6-2)\end{array}$ & $\begin{array}{l}1 \times \\
(6-3)\end{array}$ & $\begin{array}{l}5 \times \\
(6-4)\end{array}$ & $\begin{array}{l}10 x \\
(6-5)\end{array}$ & $\begin{array}{l}20 x \\
(6-6)\end{array}$ & $\begin{array}{l}30 x \\
(6-7)\end{array}$ \\
\hline
\end{tabular}

\section{Modeling iron-fertilization experiments}

M. Fujii and F. Chai

Title Page

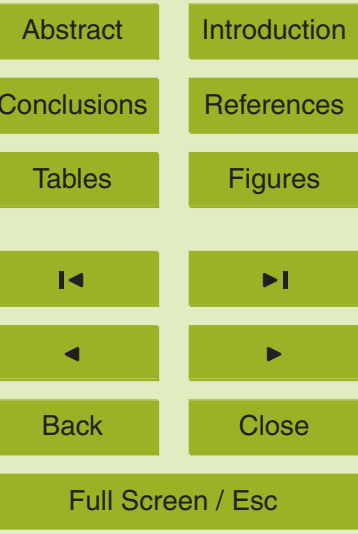

Printer-friendly Version 


\section{BGD}

4, 4411-4441, 2007

Table 2. Difference in each variable with Experiment 1 through 6 . The difference is obtained by subtracting a minimum value from a maximum value. The ratio of maximum value divided by minimum value is shown in parentheses. Experiments were for variations of Mixed Layer Depth MLD (Experiment 1), initial diatom biomass PL (Experiment 2), initial mesozooplankton biomass ZL (Experiment 3), initial non-diatom small phytoplankton biomass PS (Experiment 4), initial microzooplankton biomass ZS (Experiment 5) and initial predatory macrozooplankton biomass ZP (Experiment 6).

\begin{tabular}{|c|c|c|c|c|c|c|}
\hline & $\begin{array}{l}\text { Expt.1 } \\
\text { (MLD) }\end{array}$ & $\begin{array}{l}\text { Expt.2 } \\
\text { (PL) }\end{array}$ & $\begin{array}{l}\text { Expt.3 } \\
\text { (ZL) }\end{array}$ & $\begin{array}{l}\text { Expt.4 } \\
\text { (PS) }\end{array}$ & $\begin{array}{l}\text { Expt.5 } \\
\text { (ZS) }\end{array}$ & $\begin{array}{l}\text { Expt.6 } \\
\text { (ZP) }\end{array}$ \\
\hline Surface maximum chlorophyll [mg Chl m${ }^{-3}$ ] & $\begin{array}{l}20 \\
(10)\end{array}$ & $\begin{array}{l}14 \\
(3)\end{array}$ & $\begin{array}{l}15 \\
(4)\end{array}$ & $\begin{array}{l}6 \\
(2)\end{array}$ & $\begin{array}{l}1 \\
(1)\end{array}$ & $\begin{array}{l}2 \\
(1)\end{array}$ \\
\hline Surface maximum $\mathrm{NO}_{3}$ decrease $\left[\mathrm{mmol} \mathrm{N} \mathrm{m}{ }^{-3}\right]$ & $\begin{array}{l}14 \\
(13)\end{array}$ & $\begin{array}{l}8 \\
\text { (2) }\end{array}$ & $\begin{array}{l}11 \\
(4)\end{array}$ & $\begin{array}{l}10 \\
(3)\end{array}$ & $\begin{array}{l}3 \\
(1)\end{array}$ & $\begin{array}{l}2 \\
(1)\end{array}$ \\
\hline Surface maximum $\mathrm{Si}(\mathrm{OH})_{4}$ decrease $\left[\mathrm{mmol} \mathrm{Si} \mathrm{m}^{-3}\right]$ & $\begin{array}{l}26 \\
(7)\end{array}$ & $\begin{array}{l}10 \\
(2)\end{array}$ & $\begin{array}{l}14 \\
(2)\end{array}$ & $\begin{array}{l}7 \\
\text { (1) }\end{array}$ & $\begin{array}{l}2 \\
\text { (1) }\end{array}$ & $\begin{array}{l}2 \\
\text { (1) }\end{array}$ \\
\hline 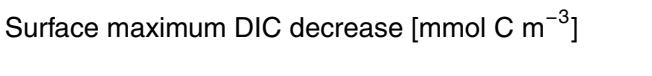 & $\begin{array}{l}56 \\
(11)\end{array}$ & $\begin{array}{l}37 \\
(3)\end{array}$ & $\begin{array}{l}54 \\
(10)\end{array}$ & $\begin{array}{l}31 \\
(2)\end{array}$ & $\begin{array}{l}13 \\
(1)\end{array}$ & $\begin{array}{l}11 \\
(1)\end{array}$ \\
\hline Maximum $\mathrm{pCO}_{2 \text { sea }}$ decrease $[\mu \mathrm{atm}]$ & $\begin{array}{l}109 \\
(8)\end{array}$ & $\begin{array}{l}67 \\
(2)\end{array}$ & $\begin{array}{l}105 \\
(7)\end{array}$ & $\begin{array}{l}55 \\
(2)\end{array}$ & $\begin{array}{l}30 \\
(1)\end{array}$ & $\begin{array}{l}22 \\
(1)\end{array}$ \\
\hline $\begin{array}{l}\text { Maximum net community production }\left[\mathrm{mg} \mathrm{C} \mathrm{m}^{-3}\right. \\
\text { day }^{-1} \text { ] }\end{array}$ & $\begin{array}{l}3100 \\
(4)\end{array}$ & (3) & $\begin{array}{l}3789 \\
(11)\end{array}$ & 2506 & $\begin{array}{l}1434 \\
(2)\end{array}$ & 905 \\
\hline Maximum export production $\left[\mathrm{mg} \mathrm{C} \mathrm{m} \mathrm{m}^{-3}\right.$ day $\left.^{-1}\right]$ & $\begin{array}{l}1651 \\
(7)\end{array}$ & $\begin{array}{l}1438 \\
(3)\end{array}$ & $\begin{array}{l}1951 \\
(15)\end{array}$ & $\begin{array}{l}1126 \\
(2)\end{array}$ & $\begin{array}{l}532 \\
(1)\end{array}$ & $\begin{array}{l}421 \\
(1)\end{array}$ \\
\hline
\end{tabular}

Title Page

Abstract Introduction

Conclusions References

Tables

Figures

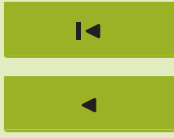

$\rightarrow$

Back

Close 


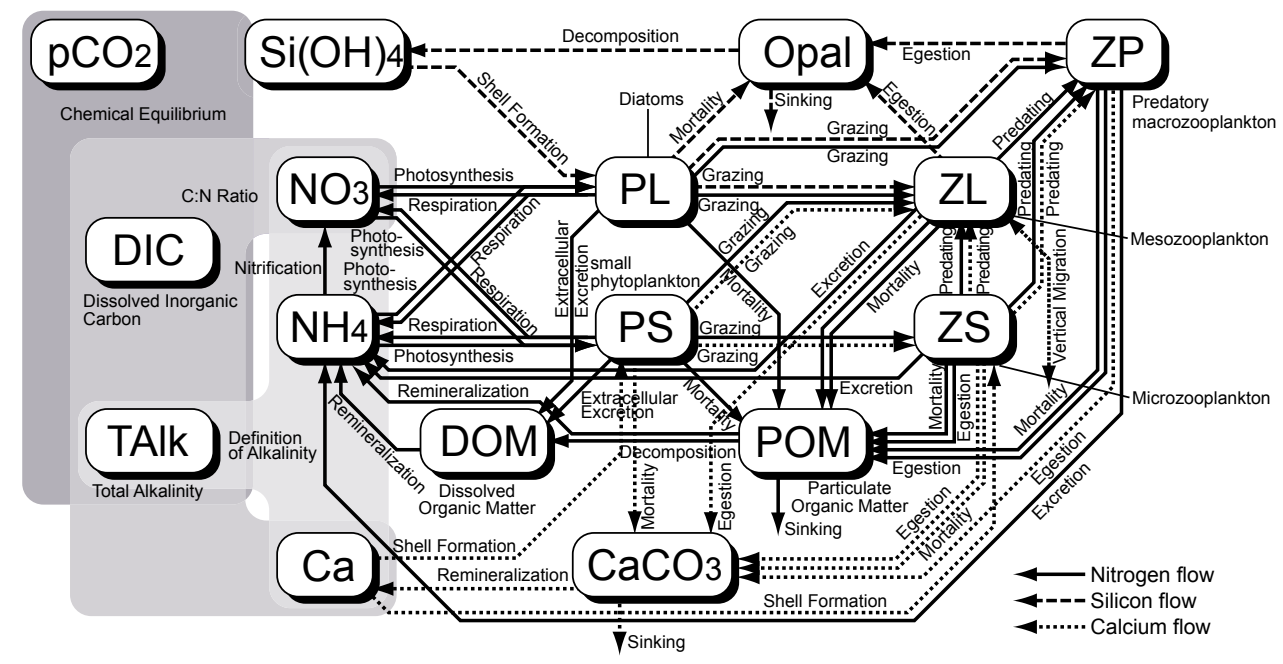

Fig. 1. Schematic view of the sixteen-compartment marine ecosystem model after Fujii et al. $(2002,2005)$ and Yamanaka et al. (2004). Here PS $\left[\mathrm{mmol} \mathrm{N} \mathrm{m}^{-3}\right]$ is non-diatom smaller phytoplankton biomass, $\mathrm{PL}\left[\mathrm{mmol} \mathrm{N} \mathrm{m}{ }^{-3}\right]$ is diatom biomass, $\mathrm{ZS}\left[\mathrm{mmol} \mathrm{N} \mathrm{m}^{-3}\right]$ is non-diatom grazing microzooplankton biomass, $\mathrm{ZL}\left[\mathrm{mmol} \mathrm{N} \mathrm{m}^{-3}\right]$ is diatom-grazing micro- or mesozooplankton biomass, ZP $\left[\mathrm{mmol} \mathrm{N} \mathrm{m}^{-3}\right]$ is predatory macrozooplankton biomass, $\mathrm{NO}_{3}\left[\mathrm{mmol} \mathrm{N} \mathrm{m}^{-3}\right]$ is dissolved nitrate, $\mathrm{Si}(\mathrm{OH})_{4}\left[\mathrm{mmol} \mathrm{Si} \mathrm{m}{ }^{-3}\right]$ is dissolved silicate, $\mathrm{DIC}\left[\mathrm{mmol} \mathrm{C} \mathrm{m}^{-3}\right]$ is total $\mathrm{CO}_{2}$ or the complete pool of dissolved inorganic carbon in seawater, and $\mathrm{pCO}_{2 \text { sea }}[\mu \mathrm{atm}]$ is the partial pressure of $\mathrm{CO}_{2}$ in seawater. The additional pools are active and dynamic part of the model simulations but not discussed in the text: $\mathrm{NH}_{4}\left[\mathrm{mmol} \mathrm{N} \mathrm{m}^{-3}\right]$ is dissolved ammonia, POM [mmol $\left.\mathrm{m} \mathrm{m}^{-3}\right]$ is particulate organic matter, DOM [mmol $\left.\mathrm{m} \mathrm{m}^{-3}\right]$ is dissolved organic matter, Opal $\left[\mathrm{mmol} \mathrm{Si} \mathrm{m}{ }^{-3}\right]$ is opal or biogenic silica frustules of diatoms, $\mathrm{Ca}\left[\mathrm{mmol} \mathrm{Ca} \mathrm{m}^{-3}\right]$ is total dissolved calcium, $\mathrm{CaCO}_{3}\left[\mathrm{mmol} \mathrm{C} \mathrm{m}^{-3}\right]$ is biogenic calcium carbonate or shells, and TAlk $\left[\mathrm{mmol} \mathrm{m}^{-3}\right]$ is total alkalinity.

\section{BGD}

4, 4411-4441, 2007

\section{Modeling iron-fertilization experiments}

M. Fujii and F. Chai

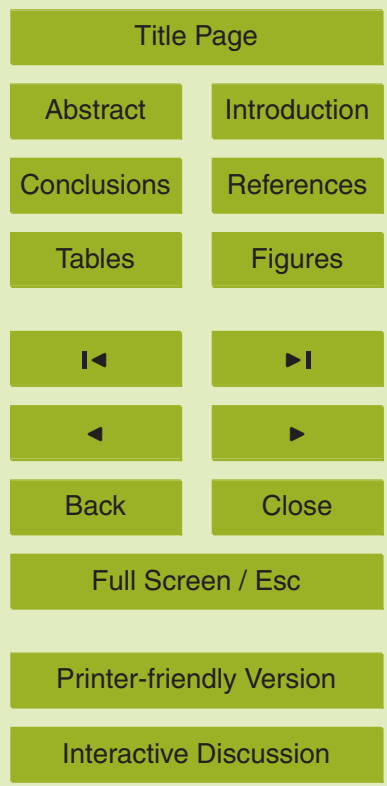

EGU 
BGD

$4,4411-4441,2007$

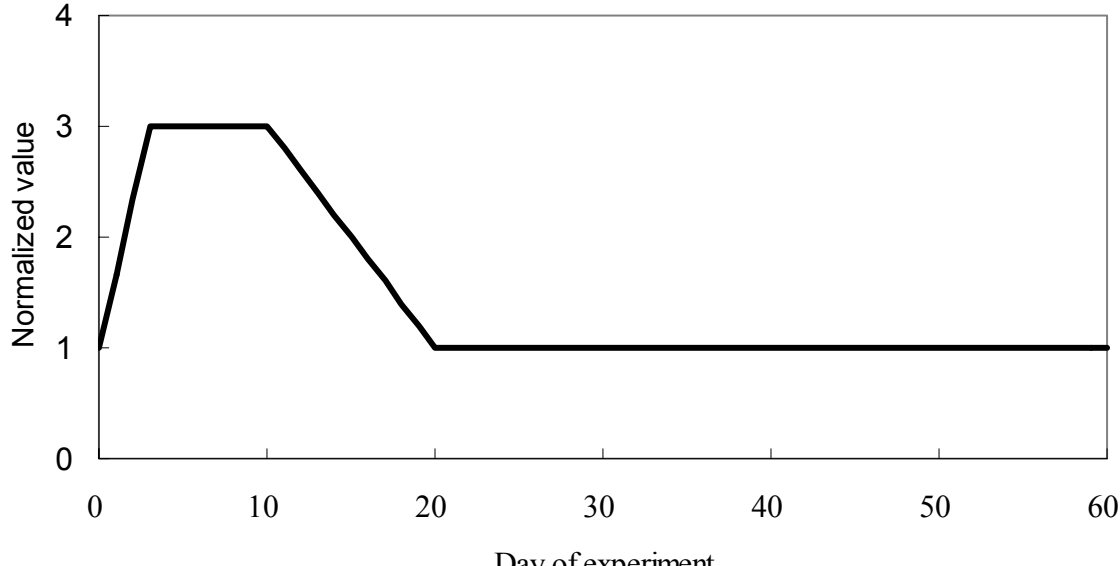

Day of experiment

Fig. 2. Temporal changes of the maximum growth rate $V_{\max L}\left[\right.$ day $\left.{ }^{-1}\right]$, the initial slope $\alpha\left[\mathrm{W}^{-1} \mathrm{~m}^{2}\right.$ day $^{-1}$ ] of the photosynthesis-irradiance (P vs. I) curve, and the chlorophyll-carbon ratio by weight for diatoms in the model from Day 0 to 60 . All three variables are set to follow identical relative changes as follows: an increase linearly from Day 0 (the date on which the iron was infused to the surface water) to Day 3 , to be kept at the maxima (by three times as high as the initial values) until Day 10, and to decrease linearly to the initial values at Day 20 , then remain constant over the Day 20 to Day 60 period.

\section{Modeling iron-fertilization experiments}

M. Fujii and F. Chai

Title Page

Abstract

Introduction

Conclusions

References

Tables

Figures

14

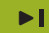

4

Back

Full Screen / Esc

Printer-friendly Version

Interactive Discussion 
(a) Experiment 1
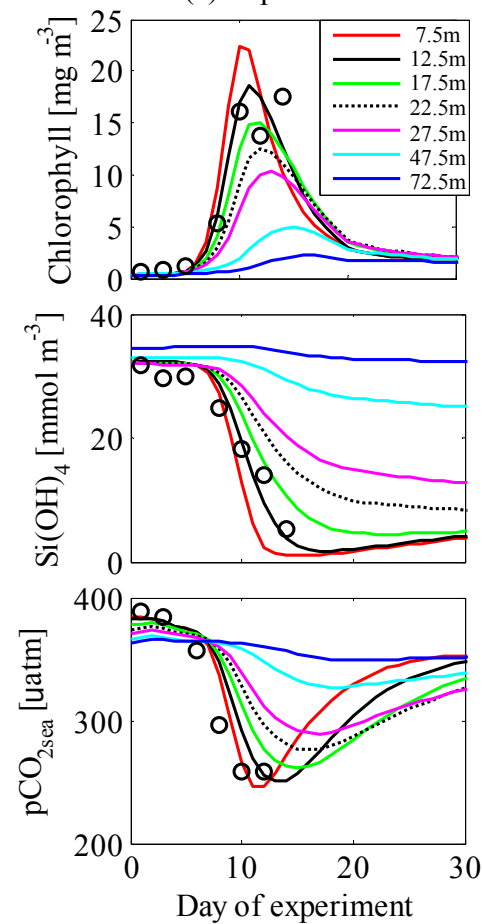

(b) Experiment 2
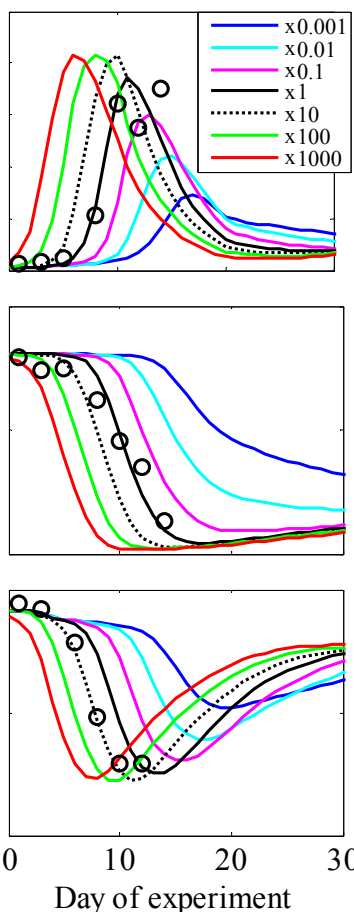

(c) Experiment 3
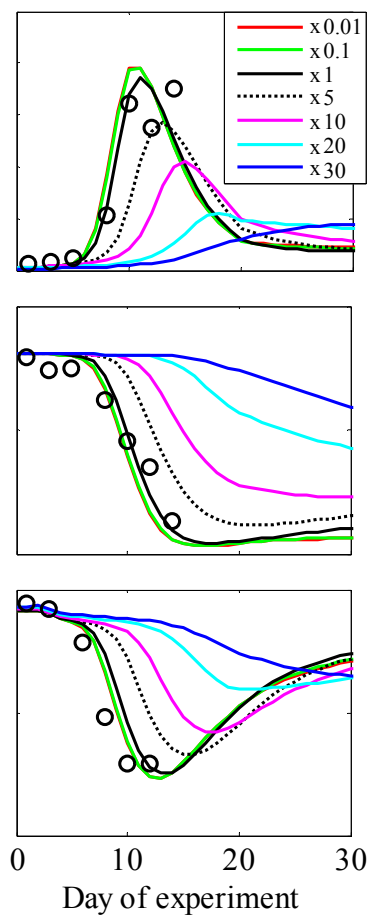

Fig. 3. Time series of modeled surface chlorophyll $\left[\mathrm{mg} \mathrm{m}^{-3}\right], \mathrm{Si}(\mathrm{OH})_{4}\left[\mathrm{mmol} \mathrm{Si} \mathrm{m}{ }^{-3}\right]$, and $\mathrm{pCO}_{2 \text { sea }}[\mu \mathrm{atm}]$ in (a) Experiment 1 varying mixed layer depth MLD, (b) Experiment 2 varying initial diatom biomass PL, and (c) Experiment 3 varying initial mesozooplankton biomass ZL. Black solid lines show model results of the standard experiment (Cases 1-2, 2-4, and 3-3). Open circles denote field observation data from SEEDS (Tsuda et al., 2003).

BGD

4, 4411-4441, 2007

\section{Modeling iron-fertilization experiments}

M. Fujii and F. Chai

\section{Title Page}

Abstract

Introduction

Conclusions

References

Tables

Figures

14

$\rightarrow 1$

4

Back

Close

\section{Full Screen / Esc}

Printer-friendly Version

Interactive Discussion 
BGD

4, 4411-4441, 2007

\section{Modeling iron-fertilization experiments}

(a)

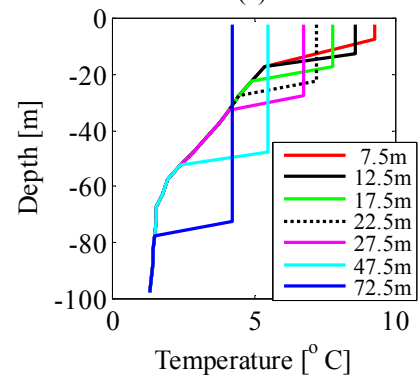

(b)

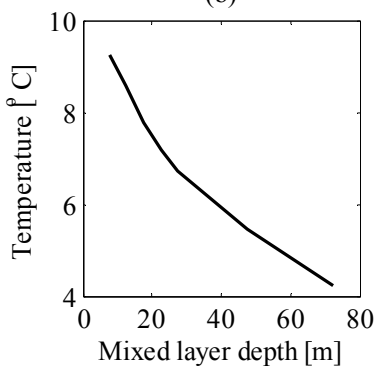

(c)

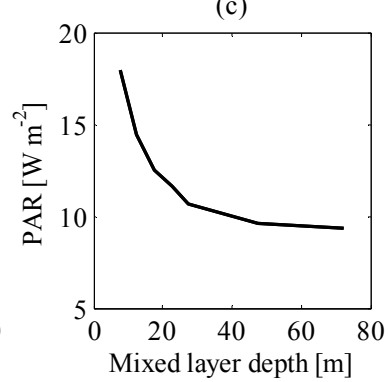

M. Fujii and F. Chai

Title Page

Abstract

Introduction

Conclusions

References

Tables

Figures

Fig. 4. Modeled (a) vertical profile of water temperature $\left[{ }^{\circ} \mathrm{C}\right]$, (b) water temperature in the mixed layer $\left[{ }^{\circ} \mathrm{C}\right]$ vs. the mixed layer depth MLD $[\mathrm{m}]$, and (c) mean PAR in the mixed layer $\left[\mathrm{W} \mathrm{m}^{-2}\right.$ ] vs. MLD [m]; all in Experiment 1 varying MLD.
I

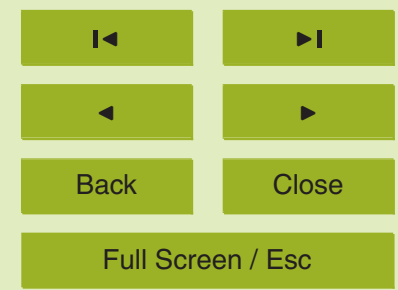

Printer-friendly Version

Interactive Discussion 
(a) Surface maximum chlorophyll $\left[\mathrm{mg} \mathrm{m}^{-3}\right]$

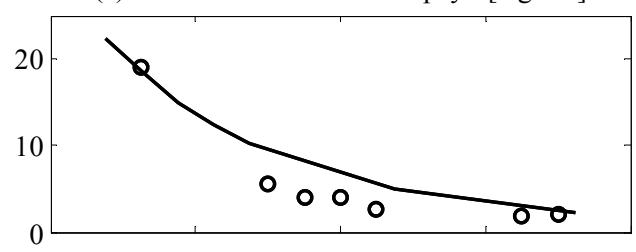

(c) Surface DIC $\left[\mathrm{mmol} \mathrm{m}^{-3}\right]$

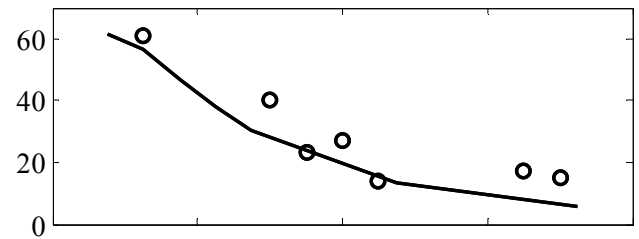

(e) $\mathrm{NCP}\left[\mathrm{mgC} \mathrm{m}^{-2}\right.$ day $\left.^{-1}\right]$

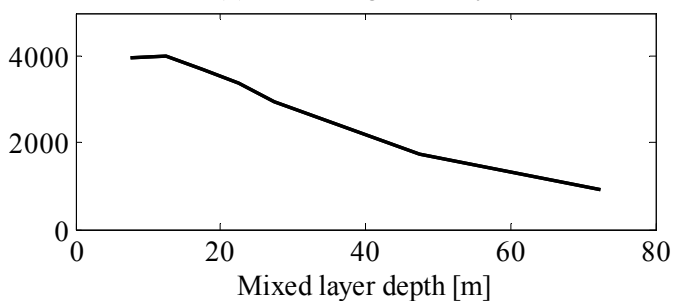

(b) Surface $\mathrm{Si}(\mathrm{OH})_{4}\left[\mathrm{mmol} \mathrm{m}^{-3}\right]$

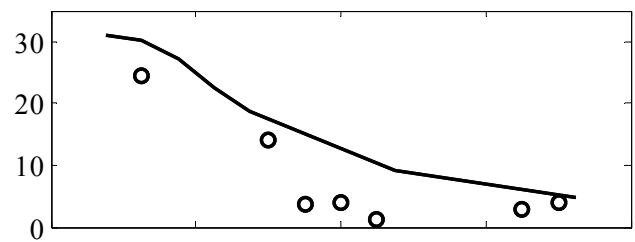

(d) $\mathrm{pCO}_{2 \text { sea }}[$ uatm]

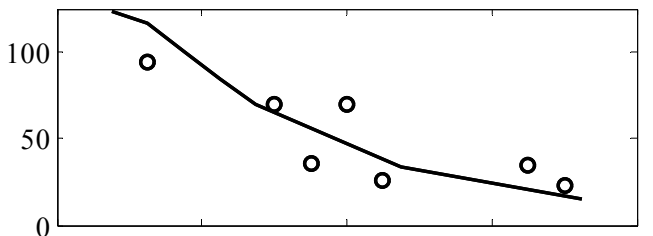

(f) $\mathrm{EP}\left[\mathrm{mgC} \mathrm{m}^{-2} \mathrm{day}^{-1}\right]$

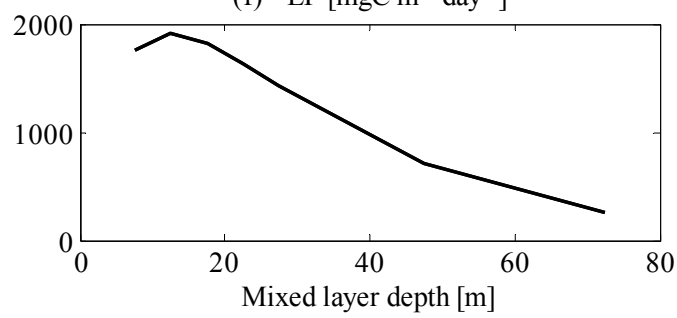

BGD

4, 4411-4441, 2007

\section{Modeling iron-fertilization experiments}

M. Fujii and F. Chai

Title Page

Abstract

Introduction

Conclusions

References

Tables

Figures

14

$\rightarrow 1$

4

Back

Close

Fig. 5-1. (a) Surface maximum chlorophyll $\left[\mathrm{mg} \mathrm{m}^{-3}\right]$, (b) $\Delta \mathrm{Si}(\mathrm{OH})_{4}\left[\mathrm{mmol} \mathrm{Sim}^{-3}\right]$, (c) $\Delta \mathrm{DIC}$

Full Screen / Esc $\left[\mathrm{mmol} \mathrm{m}^{-3}\right]$, (d) $\Delta \mathrm{pCO}_{2 \text { sea }}[\mu \mathrm{atm}]$, (e) $\Delta \mathrm{NCP}\left[\mathrm{mg} \mathrm{C} \mathrm{m}^{-2}\right.$ day $\left.^{-1}\right]$, and (f) $\Delta \mathrm{EP}\left[\mathrm{mg} \mathrm{C} \mathrm{m}^{-2}\right.$ day $^{-1}$ ]; all versus the mixed layer depth MLD [m] in Experiment 1 varying MLD. Open circles denote field observation data from eight iron-enrichment experiments (de Baar et al., 2005).

Printer-friendly Version

Interactive Discussion 
BGD

(a) Surface maximum chlorophyll $\left[\mathrm{mg} \mathrm{m}^{-3}\right]$

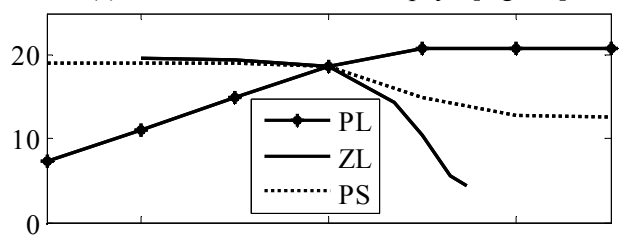

(c) Surface DIC $\left[\mathrm{mmol} \mathrm{m}^{-3}\right]$

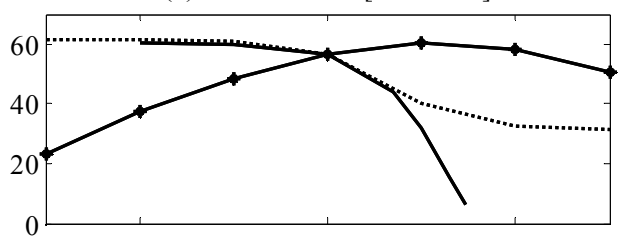

(e) NCP $\left[\mathrm{mgC} \mathrm{m}^{-2}\right.$ day $\left.^{-1}\right]$

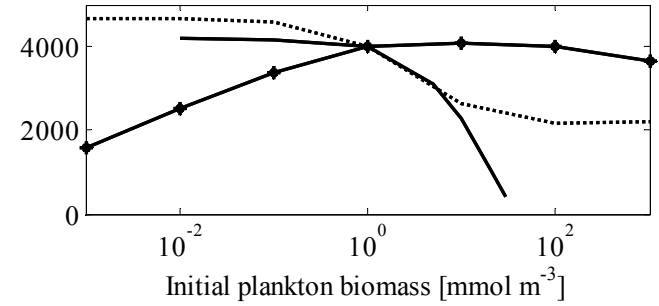

(b) Surface $\mathrm{Si}(\mathrm{OH})_{4}\left[\mathrm{mmol} \mathrm{m}^{-3}\right]$

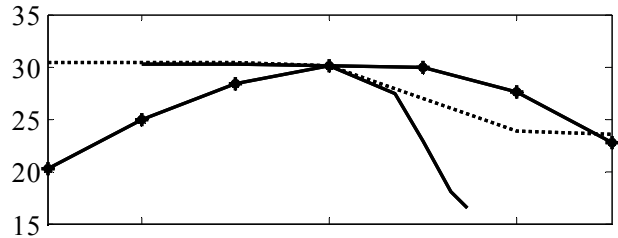

(d) $\mathrm{pCO}_{2 \text { sea }}[$ uatm]

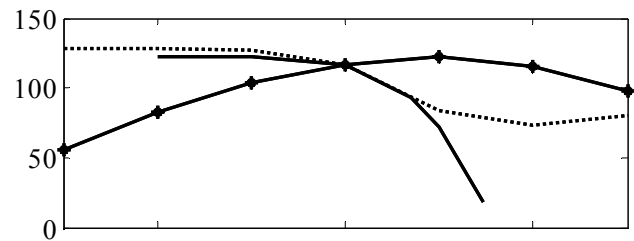

(f) $\mathrm{EP}\left[\mathrm{mgC} \mathrm{m}^{-2}\right.$ day $\left.^{-1}\right]$

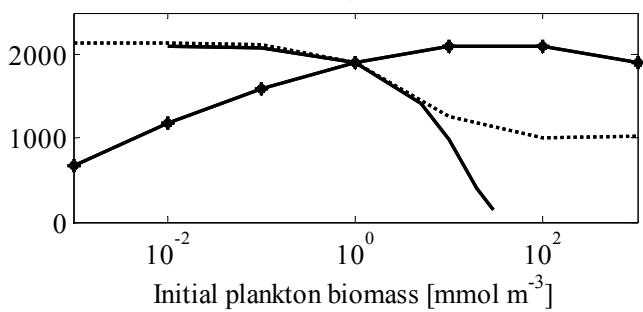

4, 4411-4441, 2007

\section{Modeling iron-fertilization experiments}

M. Fujii and F. Chai

\section{Title Page}

Abstract

Introduction

Conclusions

References

Tables

Figures

14

$>$ I

4

Back

Close

\section{Full Screen / Esc}

Printer-friendly Version

Interactive Discussion

Fig. 5-2. Same as Fig. 5-1 but for Experiment 2 varying the initial diatom biomass PL (filled diamonds), Experiment 3 varying the initial mesozooplankton biomass ZL (filled dots), and Experiment 4 varying the initial non-diatom small phytoplankton biomass PS (dotted line). 
BGD

4, 4411-4441, 2007

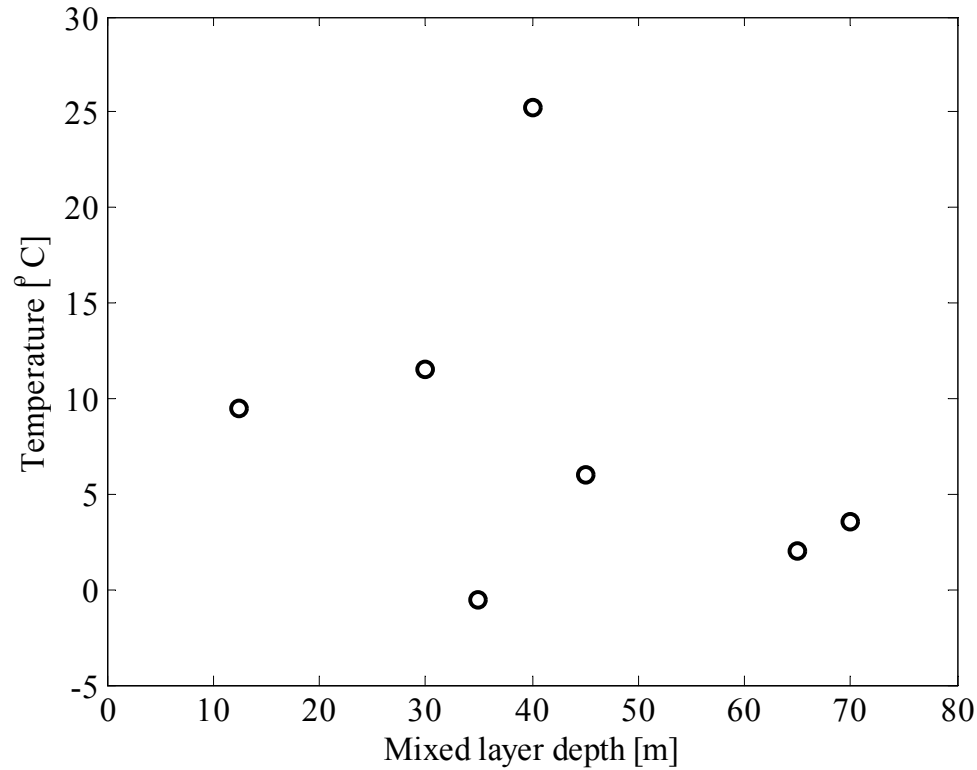

\section{Modeling} iron-fertilization experiments

M. Fujii and F. Chai

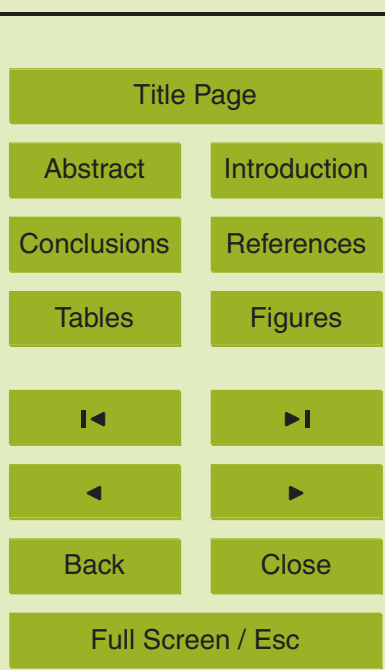

Printer-friendly Version

Interactive Discussion 
BGD
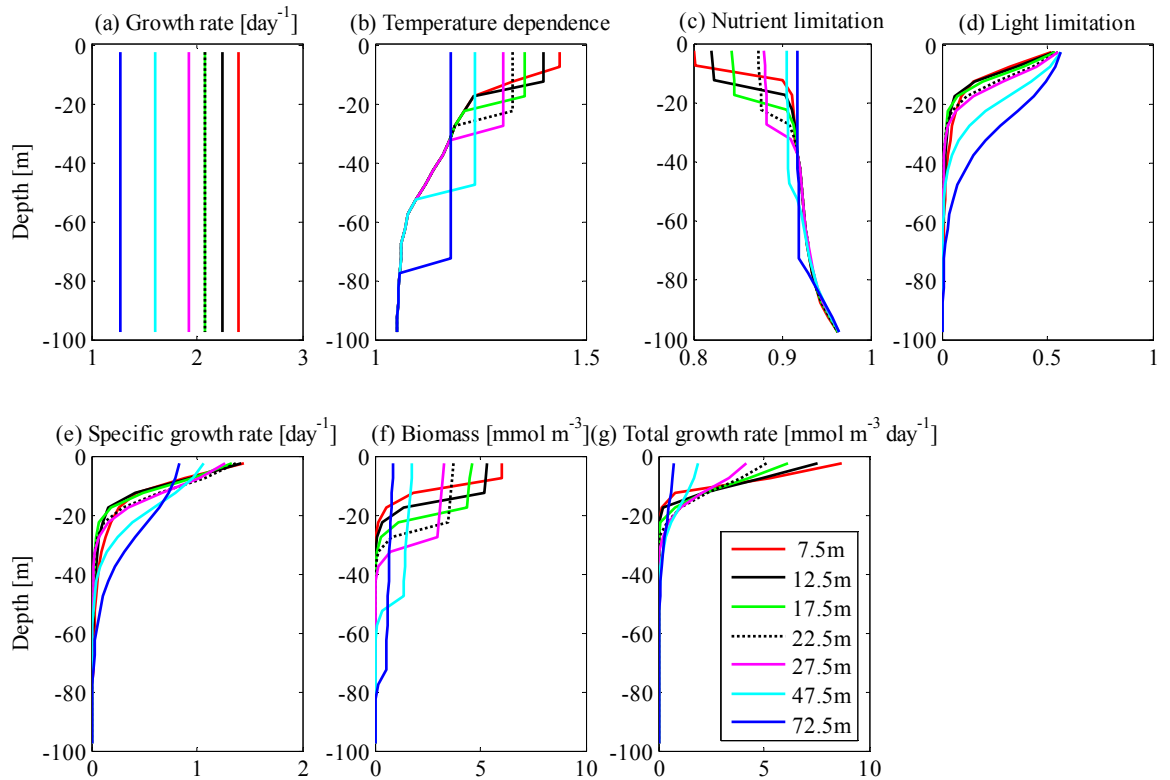

Fig. 7. Vertical profile of (a) Term 1 (the maximum diatom growth rate $V_{\max L}$ ) [day ${ }^{-1}$ ], (b) Term 2 (temperature dependence $\exp \left(k_{L} \times T\right)$ ), (c) Term 3 (nutrient limitation), (d) Term 4 (light limitation), (e) diatom specific growth rate (the product of Terms 1, 2, 3, and 4) [day ${ }^{-1}$ ], (f) Term 5 (diatom biomass) [mmol $\mathrm{m} \mathrm{m}^{-3}$ ], and $(\mathbf{g})$ diatom total growth rate (the product of Terms 1, 2, 3, 4, and 5) $\left[\mathrm{day}^{-1}\right.$ ]; all in Experiment 1 varying the mixed layer depth MLD. For the actual Terms 1-5 see Eq. (1) in main text.
4, 4411-4441, 2007

\section{Modeling iron-fertilization experiments}

M. Fujii and F. Chai

\section{Title Page}

Abstract

Introduction

Conclusions

References

Tables

Figures

14

$\rightarrow 1$

4

Back

Close

\section{Full Screen / Esc}

Printer-friendly Version

Interactive Discussion 
(a) Diatom specific growth rate $\left[\right.$ day $\left.^{-1}\right]$
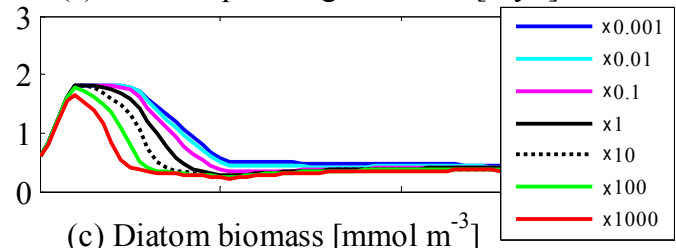

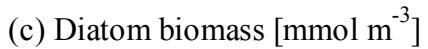

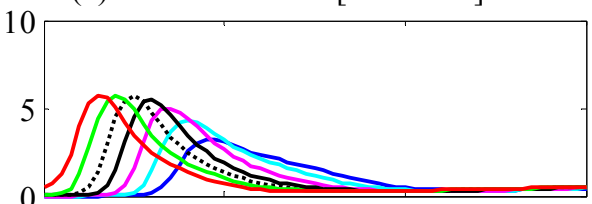

(e) Diatom total growth rate $\left[\mathrm{mmol} \mathrm{m}^{-3} \mathrm{day}^{-1}\right]$

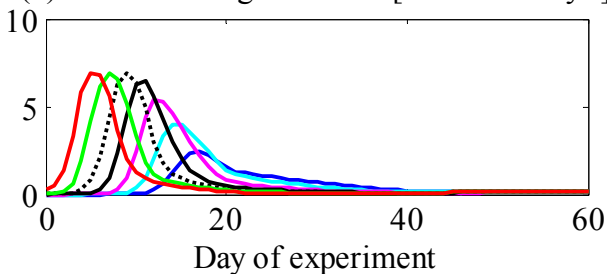

(b) Specific grazing rate by mesozooplankton $\left[\mathrm{day}^{-1}\right]$

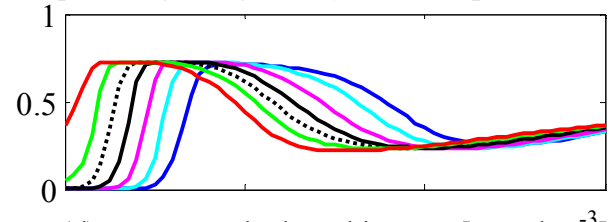

(d) Mesozooplankton biomass $\left[\mathrm{mmol} \mathrm{m}^{-3}\right.$ ]

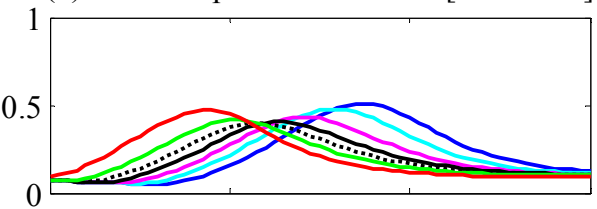

(f) Total grazing rate by mesozooplankton $\left[\mathrm{mmol} \mathrm{m}^{-3} \mathrm{day}^{-1}\right]$

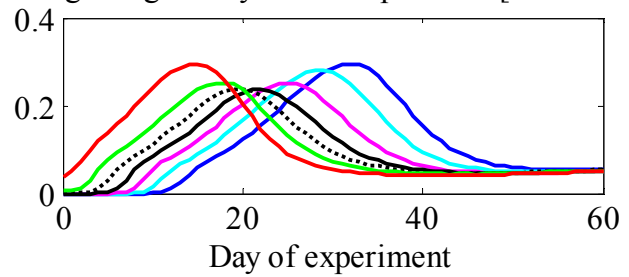

4, 4411-4441, 2007

\section{Modeling iron-fertilization experiments}

M. Fujii and F. Chai

Title Page

Abstract

Introduction

Conclusions

References

Tables

Figures

14

$\rightarrow 1$

4

Back

Close

\section{Full Screen / Esc}

Printer-friendly Version

Interactive Discussion 
BGD

4, 4411-4441, 2007

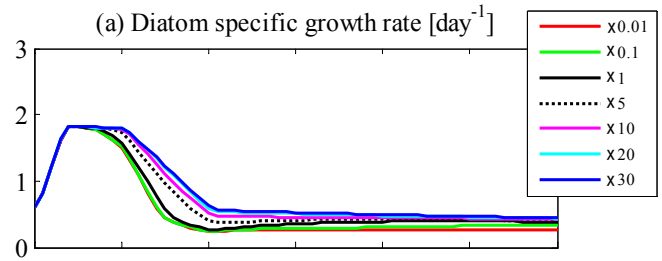

(c) Diatom biomass $\left[\mathrm{mmol} \mathrm{m}^{-3}\right]$

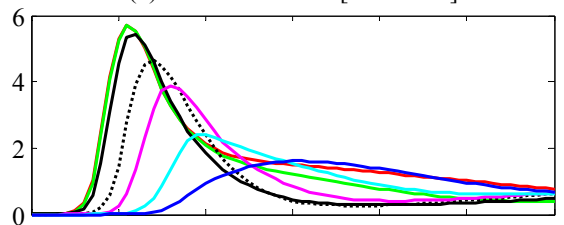

(e) Diatom total growth rate $\left[\mathrm{mmol} \mathrm{m}^{-3}\right.$ day $\left.^{-1}\right]$

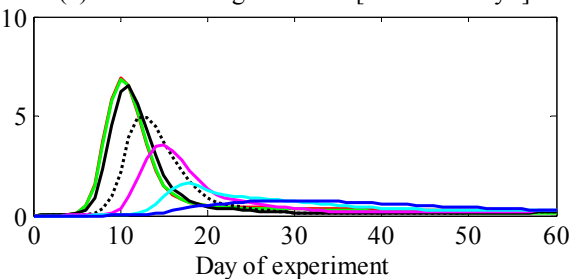

(b) Specific grazing rate by mesozooplankton $\left[\right.$ day $^{-1}$ ]

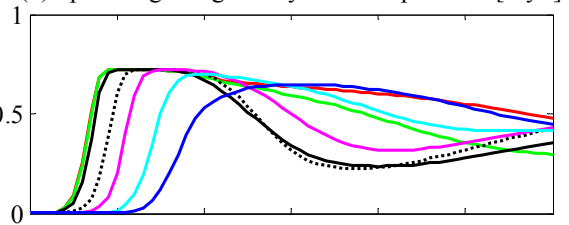

(d) Mesozooplankton biomass $\left[\mathrm{mmol} \mathrm{m}^{-3}\right]$

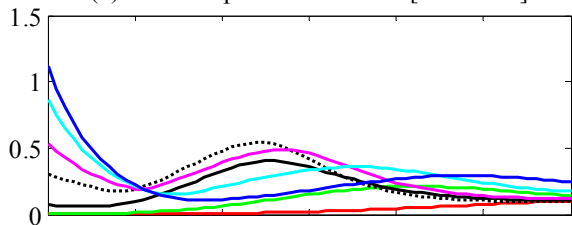

(f) Total grazing rate by mesozooplankton $\left[\mathrm{mmol} \mathrm{m}^{-3}\right.$ day $\left.^{-1}\right]$

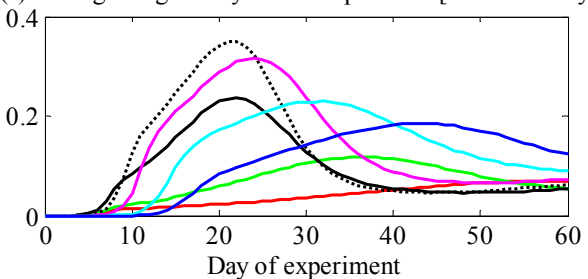

Title Page

Abstract

Conclusions

Tables

14

4

Back
Modeling iron-fertilization experiments

M. Fujii and F. Chai

\section{Full Screen / Esc}

Printer-friendly Version

Fig. 8-2. Same as Fig. 8-1 but for Experiment 3 varying the initial mesozooplankton biomass ZL.

Interactive Discussion 